This item was submitted to Loughborough's Research Repository by the author.

Items in Figshare are protected by copyright, with all rights reserved, unless otherwise indicated.

\title{
Securitization and lending standards: Evidence from the European wholesale loan market
}

PLEASE CITE THE PUBLISHED VERSION

http://dx.doi.org/10.1016/j.jfs.2016.07.004

PUBLISHER

(C) Elsevier

VERSION

AM (Accepted Manuscript)

\section{PUBLISHER STATEMENT}

This work is made available according to the conditions of the Creative Commons Attribution-NonCommercialNoDerivatives 4.0 International (CC BY-NC-ND 4.0) licence. Full details of this licence are available at: https://creativecommons.org/licenses/by-nc-nd/4.0/

\section{LICENCE}

CC BY-NC-ND 4.0

\section{REPOSITORY RECORD}

Kara, Alper, David Marques-lbanez, and Steven Ongena. 2016. "Securitization and Lending Standards: Evidence from the European Wholesale Loan Market”. Loughborough University. https://hdl.handle.net/2134/22113. 


\title{
Securitization and lending standards: Evidence from the European wholesale loan market*
}

\author{
Alper Kara \\ (Corresponding Author) \\ Loughborough University, School of Business and Economics, \\ LE11 3TU Loughborough, UK, \\ Tel: +441509227091,e-mail:a.kara@,lboro.ac.uk. \\ David Marques-Ibanez \\ European Central Bank, \\ Financial Research Division, \\ Kaiserstrasse 29, D-60311 Frankfurt am Main, Germany, \\ Tel: +49691344 6460,e-mail: david.marques@,ecb.int. \\ Steven Ongena \\ University of Zürich, SFI and CEPR \\ Department of Banking and Finance, \\ Plattenstrasse 32, CH-8032 Zürich, Switzerland, \\ Tel: +4144634 3954, e-mail: steven.ongena@,bf.uzh.ch.
}

\begin{abstract}
We assess the effect of securitization activity on banks' lending rates employing a uniquely detailed dataset from the euro-denominated syndicated loan market. We find that in the run-up to the 2007-2009 crisis banks more active at originating asset-backed securities did not price their loans more aggressively (i.e. with narrower lending spreads) than non-active banks. We show that also within the set of loans that were previously securitized, the relative level of securitization activity by the originating bank is not related to narrower lending spreads. Our findings, which are limited to the cross-sectional impact of securitization, suggest that the effect of securitization on the cost of corporate funding appears to be quite limited.
\end{abstract}

JEL classification: G21, G28.

Keywords: securitization, lending standards, syndicated loans, financial crisis.

\footnotetext{
* E-mail addresses: a.kara@,lboro.ac.uk, david.marques@ecb.int and steven.ongena@bf.uzh.ch. The authors thank, in particular, the editor Iftekhar Hasan, Joao Santos, Jose Luis Peydro, John Rogers and anonymous referees from the Journal of Financial Stability and European Central Bank (ECB) working paper series for useful comments and early discussions. Our thanks also to participants at seminars held at the ECB, Bangor University, University of Hull and the 4th IFABS 2012 Valencia conference on "Rethinking Banking and Finance: Money, Markets and Models" for their useful comments. We are also most grateful to Raffaele Passaro and Luiz Paulo Fichtner for their help with the data and suggestions. We would also like to thank Oliver Goß and Priti Thanki from Standard and Poor's and, in particular, Jean-Paul Genot for their invaluable help finding data on securitized syndication credit from all major securitization trustees in Europe. The opinions expressed in this paper are those of the authors only and do not necessarily reflect those of the ECB or the Board of Governors of the Federal Reserve.
} 


\section{Introduction}

2007-2009 financial crisis has shown that securitization could be a major danger to financial stability (Financial Crisis Inquiry Commission 2011). Specifically, securitization has been suspected to endanger financial stability by weakening banks credit standards and thereby fuelling excessive risktaking (Keys et al. 2011). Prior to the crisis, however, the usual view emphasized the positive role played by securitization in supporting financial stability by dispersing credit risk. This was also the prevalent view in policy circles empowered with maintaining financial stability (see for instance Greenspan 2005). As a result, securitization activity was expected to make the financial system more stable as risk was more easily diversified, managed and allocated economy-wide. From the perspective of individual institutions, securitization was believed to be employed by banks to manage and diversify more effectively their credit risk portfolio. Consequently, if the total risk remained within the banking sector, securitization was thought to allow banks to lower their overall risk profile via diversification [(Cebenoyan \& Strahan 2004); (Jiangli et al. 2007); (Duffie 2008)].

At the same time, there were growing concerns about the possible effects of financial innovation on financial stability. In particular, securitization could compound adverse selection and moral hazard problems in banking leading to poorer screening standards as well as weaker monitoring of borrowers. Mostly building on this argument, there was a more skeptical view on the final impact of securitization on the stability of the financial system (Rajan 2006). It was also argued that securitization could undermine lending standards [(Greenbaum \& Thakor 1987); (Gorton \& Pennacchi 1995) $]^{1}$ and enhance banks' risk appetite [(Calem \& LaCour-Little 2004); (Ambrose et al. 2005); (Brunnermeier \& Sannikov 2014)]. If securitization activity leads to excessively lax lending standards by banks' it could have an impact on the overall financial stability by building up imbalances on credit markets that can make the overall system more fragile.

Following the 2007-2009 financial crisis, evidence on the link between securitization and bank risk-taking is growing. Part of the literature argues that banks resorting to securitization activity relaxed their lending standards in the years prior to the crisis more aggressively, making the overall financial system less stable [(Dell'Ariccia et al. 2012); (Nadauld \& Sherlund 2013); (Wang \& Xia 2014)]. Other studies do not find any evidence suggesting that securitization led to riskier lending [see for

\footnotetext{
${ }^{1}$ See also DeMarzo (2005), Instefjord (2005), Morrison (2005), Chiesa (2008), Parlour and Plantin (2008) and Shin (2009).
} 
instance Benmelech et al. (2012)]. Overall and partly due to data availability the findings on the effects of securitization remain ambiguous and centered in the United States.

In this paper we assess the impact of banks' securitization activity on their lending function. In particular on their lending rates for euro-denominated loans as we test whether banks that were active in the securitization market priced loans more aggressively, via tighter spreads, as they were able to sell these loans to other investors via securitization. If securitization activity increases banks' risk appetite when extending loans, we would observe lower spreads for these loans compared to loans extended by banks not active in this market. It is important to note that our analysis is relative as it is limited to the cross-sectional dimension of the relationship between securitization and the cost of corporate credit. We focus on pricing differences of syndicated loans associated with banks' securitization activity and, as a result, our paper does not provide evidence on a so-called "level effect". For instance, an increase in securitization activity by banks might induce a decrease in the overall cost of funding for all syndicated loans, or other types of credit.

We investigate this at two levels. We start by examining the pricing behavior of banks in the syndicated loan market by comparing banks active in the securitization market to those who are nonactive in this market. This approach has the advantage of examining banks' lending standards by including first-hand information on bank, borrower and loan conditions. This should, in turn, give an indication of banks' changes in risk-taking appetite. In our second step we consider only those banks that are already active as originators in the securitization market and include only those loans that were securitized. This step aims to reduce possible concerns about self-selection across bank or instruments connected to securitization by considering only the variability within those banks that are already active in the securitization market, and within those loans which have been securitized. We select a group of 406 broadly similar European banks - 94 of which were active in the securitization market -, and 10,911 syndicated loan deals for the period ranging from 2000 to 2009.

We contribute to the literature in several dimensions. The coverage and quality of our dataset constitutes an significant additional to the literature. Our sample has been obtained directly from the largest trustees operating in the European Union and covers the overwhelming majority of the syndicated loans issued in euro. This is an important advantage as data from previous studies was mostly limited to public deals as reported by publicly available sources. In contrast, we are able to form a more complete picture of the market, which also includes private deals. In addition, the dataset allows us to identify, among all syndicate loan transactions, those that were eventually securitized. 
Utilizing this dataset gives us the advantage of examining banks' pricing behavior of loans with firsthand information on their lending practices.

The focus on the European Union, the second largest securitization market in the world, is another contribution of our paper as most of the existing evidence is based on the United States. The European Union is a good laboratory to assess the impact of securitization on financial stability. First, the growth of the securitization market in the European Union has been relatively recent and brusque. This allows us to assess more clearly the impact of this recent phenomenon (i.e. securitization) on lending standards. Second, unlike in the United States, where institutions such as Fannie Mae and Freddie Mac have supported the securitization market, government-sponsored institutions have not driven the development of the securitization market in the European Union. Hence our results cannot be ascribed to any individual institutional or regulatory features idiosyncratic to any single country.

Another contribution is our focus on securitization in the corporate loan market, which stands in contrast with the bulk of the previous securitization literature that usually analyzes the mortgage market. Corporate lending decisions are more dependent on idiosyncratic, and often proprietary, information on the credit quality of borrowers. Looking at corporate loans gives more insights to the extent of how securitization might undermine screening and monitoring incentives of lenders, and thereby weaken financial stability, when information asymmetries are larger.

We find that in the run up to the 2007-2009 crisis, banks that were more active at originating asset-backed securities did not price their loans more aggressively (i.e. with narrower loan spreads) than non-active banks. Our results also show that larger banks with relatively smaller securitizationorigination programs seem to be somewhat more aggressive than other banks in their loan pricing. In addition, we show that, within the set of loans that were securitized, the amount of securitization activity by the originating bank is not related to lower loan spreads. Our results consistently suggest that broad credit cycle conditions seem to be far more correlated with looser credit standards (measured via price aggressiveness) than banks' securitization activity.

We test the robustness of our findings extensively. In particular we try to account for the possible effects of the syndicate structure, lead banks' influence, and borrower opacity on our findings (see Sufi 2007). We run our models with restricted samples where information asymmetries are mitigated by the use of incidences of repeated lending, i.e. limiting our sample to those occasions in which the lender already knows the borrower. We also control for syndicate and lead bank fixed effects. Finally we also conduct our analysis at the syndicate level. Our results remain unchanged. 
The remainder of this paper is organized as follows: Section 2 reviews the related literature on the effects of securitization on lending standards and risk-taking behavior. Section 3 describes the data sources, reports the descriptive statistics of our sample and explains the empirical methodology used in the analysis. The results of estimations and robustness checks are presented in Section 4 and Section 5, respectively. Section 6 concludes.

\section{Background and literature review}

\subsection{European securitization market developments}

Public euro-denominated securitization markets started timidly in the late 1990s and gained momentum upon the introduction of the Euro in 1999 and the integration of the European financial system. The market accelerated strongly and increased in size: From US $\$ 230$ billion in 2003 to US $\$ 2$ trillion in 2008. Total amounts outstanding peaked at US\$3.1 trillion at the end of 2009 and by 2014 it has felt by 39\%. During the pre-crisis period, greater part of securitization issuances were successfully placed with end investors. Due to loss of investor confidence, public issuances dried up after the eruption of the crisis. For example in 2009 only $6 \%$ of gross issuances were placed. Following the crisis European securitization has been weak compared to the US market due to the departure of key investors like bank conduits, structured investment vehicles and bank trading books. Currently, the key investors include foreign banks, pension funds, insurance companies and asset managers (Pengelly, 2012).

Regulation of securitization markets has changed substantially since the financial crisis. As part of Basel III, a revised securitization framework is introduced in December 2014 reinforcing capital standards for securitization exposures. These changes also addressed the limitations of the Basel II framework including inadequate risk coverage, perfunctory dependence on credit ratings, inappropriate risk weights for securitization exposures and cliff effects (BCBS, 2014). The new Capital Requirements Regulation requires originators and sponsors to perpetually retain a minimum of 5\% net economic interest in originated securitizations and prohibits the hedging or sale of the retained interest. Originating and sponsoring banks must make known to investors their degree of commitment in relation to retention. Banks should also publicly disclose any form of implicit (noncontractual) support that has been provided to the securitized notes and the capital implications of this provision. Recent evidence shows that a securitization instrument that retains risk may induce a 
more prudent risk behavior of banks than an instrument that provides only risk transferring (CarboValverde et al. 2015). It is also argued that equity tranche retention is an incentive for the bank to maintain monitoring incentives (Cerasi \& Rochet 2014) and maximizes loan screening (Kiff \& Kisser 2014). Furthermore, since 2013, the European Central Bank made mandatory for banks to provide loan level data for ABS as an eligibility requirement for its repo transactions.

\subsection{Literature review}

The advent of securitization changed banks' role progressively from traditional relationship-based lending towards originators and distributors of loans and would be expected to have implications for banks' incentives to take on new risks. ${ }^{2}$ Securitization can be broadly defined as the process whereby individual bank loans and other financial assets are bundled together into tradable securities, which are then sold on to investors. Securitization allowed banks to transform traditionally illiquid claims (overwhelmingly in the form of bank loans) into marketable securities. The development of securitization has permitted banks to "off-load" part of their credit exposure to outside investors thereby lowering regulatory pressures on capital requirements, raise new funds and increase lending further.

In principle, the overall view prior to the 2007-2009 crisis was that in addition to allowing lenders to conserve costly capital, securitization improved financial stability by smoothing out the risks among many investors (Duffie 2008). Scant early empirical evidence show that through loan sales banks improve their ability to manage credit risk (Cebenoyan \& Strahan 2004) and increase profitability and leverage but reduce overall insolvency risk (Jiangli et al. 2007). Securitization also has a direct positive impact on the quantity of loans supplied by banks. It reduces banks' holdings of liquid securities and increases their lending ability [for United States (Loutskina \& Strahan 2009); (Loutskina 2011); for Europe (Altunbaş et al. 2009)]. ${ }^{3}$ Positive effects of securitization on bank lending function may also lead to lower financing costs for borrowers [(Nadauld \& Weisbach 2012); (Kamstra et al. 2014)].

\footnotetext{
${ }^{2}$ Rapid developments in securitization markets altered banks' role. Banks have long been recognized as "special" because of their ability to act as intermediaries between borrowers and depositors and transform illiquid assets into liquid deposit contracts. Conventionally, bank lending was typically conducted on the basis of a bank extending a loan to a borrower, holding the loan on their balance sheet until maturity and monitoring the borrower's performance along the way. In this relationship-based model, banks reduced idiosyncratic risks mainly through portfolio diversification and performed the role of delegated monitors for less informed investors [(Diamond 1984); (Ramakrishnan \& Thakor 1984); (Bhattacharya \& Chiesa 1995); (Holmstrom \& Tirole 1997)].

3 Also, Hirtle (2009) provides evidence suggesting that greater use of credit derivatives is associated with greater supply of bank credit for large loans with longer maturity, and lower spreads for newly negotiated loan extensions to large corporate borrowers.
} 
While risk sharing within the financial sector (through securitization and derivatives contracts) contributes to diversify risks, it can also amplify bank risks at the systemic level (Brunnermeier \& Sannikov 2014) and may have possible harmful effects on financial stability. Banks have a special role in monitoring and screening borrowers thereby mitigating moral hazard between borrowers and lenders [(Diamond 1984); (Fama 1985); (Boyd \& Prescott 1986)]. By creating informational "distance" between the loan's originator and the bearer of the loan's default risk, securitization can potentially reduce lenders' incentives to carefully screen and monitor borrowers (Petersen \& Rajan 2002). As a result, loan sales and securitization are associated to looser credit monitoring incentives by banks' [(Gorton \& Pennacchi 1995); (Duffee \& Zhou 2001); (Morrison 2005); (Chiesa 2008); (Parlour \& Plantin 2008)].

Securitization may destabilize the financial system by making the acquisition of further risk more attractive for banks. Banks behave more aggressively in acquiring new risks when they have access to a richer set of tools to manage risk than before (Instefjord 2005) and increase their loan-toasset ratio subsequent to the first issuance of a collateralized loan obligation (CLO; Goderis et al. 2007). ${ }^{4}$ Empirical evidence show that in Europe collateralized debt obligation (CDO) market enhanced the risk appetite of the banks (Haensel \& Krahnen 2007) and credit risk securitization had a negative impact on banks' financial soundness (Michalak \& Uhde 2013). Furthermore, greater liquidity of bank assets achieved through securitization, paradoxically, increases banking instability and the externalities associated with banking failures as banks have stronger incentives to take on new risks (Wagner 2007). ${ }^{5}$ The reason is that securitization makes crises less costly for banks and, as a result, banks have an incentive to take on new risks offsetting the positive direct impact of securitization on bank stability.

In the pre-crisis period securitization was thought by some authors to pose a potential threat to financial stability as it provided banks a mechanism to undertake regulatory capital arbitrage. Securitization has often been used by some banks to lower their regulatory needs for costly equity capital charges related to their loan book, thereby reducing their overall cost of financing (Watson \& Carter 2006). At the same time, banks also had an incentive to securitize less risky loans thereby increasing their risk profile for a given level of capital (Calem \& LaCour-Little 2004). This behavior was driven from the existence of high capital standards which possibly induced banks to exploit the

\footnotetext{
${ }^{4}$ Foos et al. (2010) show that bank loan growth leads to higher bank risk, including a worsening of the risk-return structure and worse (i.e. lower) bank solvency.

${ }^{5}$ In addition, for Europe Affinito and Tagliaferri (2010) show that in Italy banks that were less capitalized, less profitable, less liquid and burdened with troubled loans were more likely to perform securitization during the period of 2000-2006.
} 
benefits of securitizing assets in order to undertake regulatory capital arbitrage. Through securitization banks could have potentially increase capital adequacy ratios without decreasing their loan portfolios' risk exposure. In other words, banks had the choice of securitizing less risky loans and keep the riskier ones. There is some empirical support for these arguments as securitized loans are found to experience lower ex-post defaults than those retained in banks' balance sheets (Ambrose et al. 2005) and loans are not granted at lower lending standards compared to those remaining on banks' balance sheets (Albertazzi et al. 2015). ${ }^{6}$ As mentioned above regulations of the securitization market has changed in the post-crisis period limiting such arbitrage possibilities.

Systemic risk of banks after securitization may also increase due to the retention of first loss piece (Krahnen \& Wilde 2008), or other riskier tranches, on their balance sheet in order to signal the quality of the securitized assets and align its interests with those of investors. The objective is to bridge asymmetries of information between originators and the final investor. Retention is the result of a signaling equilibrium where the securitizing bank, in an attempt to signal the value of assets, retains poorer quality assets [(Greenbaum \& Thakor 1987); (DeMarzo 2005); (Instefjord 2005)]. ${ }^{7}$

Overall, a large part of the pre-crisis literature on securitization argues that it may weaken financial stability. In this direction, the crisis has vividly shown how the securitization market is heavily dependent on markets' perceptions and could be subject to sudden concerns or changes in risk or liquidity aversion by investors. Namely, the consequences of the increased participation in bank funding by financial markets' investors coupled with the large increases in securitized assets, often financed by short-term liquid liabilities, can lead to liquidity crises.

Following the 2007-2009 crisis, empirical evidence examining the relationship between securitization and risky lending practices has expanded. Banks' which resort to securitization activity in the years prior to the crisis seem to show a sharp decline in lending standards [(Keys et al. 2011); (Dell'Ariccia et al. 2012); (Nadauld \& Sherlund 2013)] and in the quality of mortgage credit in the United States (Mian \& Sufi 2009). This decline was more prevalent in areas with higher mortgage securitization origination. Securitized mortgages also had higher prepayment risk than the ones kept in the portfolio and the banks became less willing to retain higher default loans after the housing market reached its peak in the United States (Agarwal et al. 2012). Recent results suggest that banks securitized ex-ante their riskiest mortgages and that following securitization the delinquency rates for

\footnotetext{
${ }^{6}$ They find that banks can effectively counter the negative effects of asymmetric information in the securitization market by selling less opaque loans via signaling or building up a reputation for not undermining their own lending standards.

${ }^{7}$ Holders of senior tranches are exposed to sizable "tail risk", i.e. the risk of very infrequent but catastrophic losses (Coval et al. 2009$)$.
} 
securitized mortgages were higher than for non-securitized ones [(Krainer \& Laderman 2014); (Elul 2015)]. Securitized corporate loans also showed an inferior credit performance after securitization (Bord \& Santos, 2015). Furthermore, securitization active banks imposed looser covenants on borrowers at origination and were more likely to grant waivers without changing loan terms (Wang \& Xia 2014). ${ }^{8}$

In stark contrast, other recent evidence contradicts the findings on the negative impact of securitization on bank lending standards. For example, Benmelech et al. (2012) find that corporate loans securitized before 2005 performed no worse than comparable non-securitized corporate loans originated by the same bank. Casu et al. (2013) argue that the net impact of securitization on the risktaking behavior of issuing banks, and consequently on the soundness of the banking system, is ambiguous and will depend on the structure of the transaction. ${ }^{9}$

In sum, the theoretical literature tends to emphasize the undesirable consequences of securitization on financial stability. In particular it shows that it may encourage banks undermine screening and monitoring incentives and increase banks' broad risk appetite. The empirical evidence however, seems to provide us with contradictory findings in this respect. Some of the studies find that securitization active banks tend to lend to riskier borrowers, hold less capital, and retain riskier loans. In contrast, there is also evidence suggesting that securitization reduces banks' insolvency and liquidity risks. One area where the existing literature provides clear evidence is on the mortgage securitization market in the United States as studies uniformly found that banks active in mortgage securitization market systemically originated loans of poorer quality mortgages due to loser screening and monitoring.

We contribute to this literature by providing evidence from securitization in the corporate loan market in Europe. This seems important as the bulk of the evidence focuses on mortgage securitization in United States where existence of government sponsored agencies might have had an impact on the effect of securitization on banks risk taking incentives. ${ }^{10}$ Europe, where such institutions do not exist, provides a distinct setting to explore the impact of securitization on banks'

\footnotetext{
${ }^{8}$ Furthermore, it is documented that prior to the financial crisis asset misreporting by banks was extensive within the securitization chain [(Piskorski et al. 2015); (Griffin \& Maturana 2015)]. In theory, the risk of losing long run reputation should motivate banks to avoid such opportunistic behavior and produce good securities (Chemmanur \& Fulghieri 1994); however, this intuition may be insufficient when dealing with relatively complex securities and structured securities issued by reputable underwriters performed much worse during the financial crisis (Griffin et al. 2014).

${ }^{9}$ More specifically, Shivdasani and Wang (2011) argue that an increase in securitization did not lead to riskier leveraged buyouts. However, they raise the question of whether investors of structured credit were adequately compensated for their risks given the lower spreads, higher leverage and weaker covenant protection they report in their results.

${ }^{10}$ In the United States the market for ABS started to develop by means of government-sponsored agencies such as the Federal National Mortgage Association, a.k.a. Fannie Mae, and the Federal Home Loan Mortgage Corporation, a.k.a. Freddie Mac, created in 1938 and 1968, respectively. These agencies enhanced mortgage loan liquidity by issuing and guaranteeing, but not originating, ABS. See Acharya et al. (2014) for a discussion.
} 
behavior, especially during a period where policy makers are discussing the revival of securitization. Furthermore, securitization activity grew steadily in the Unites States since the early 1970s whereas in Europe it showed an extraordinary growth in a very short period of time prior to the start of the financial crisis. As a result the effect of securitization on bank behavior might be very different in Europe compared to the United States.

\section{Methodology and data}

\subsection{Model}

We start our analysis at the bank level by considering whether banks active in the securitization market were pricing similar loans differently than non-active banks using evidence from the syndicated loan market. In other words, we examine if banks making greater use of the securitization market were more aggressive in their loans' pricing. Hence we use the pricing of newly extended loans (measured as the spread charged) as a potential proxy for banks' credit standards after securitization.

Building on earlier literature we include loan spread at the loan level so we model loan $i$ by bank $b$ at time $t$, as a function of a number of factors [(Carey \& Nini 2007); (Ivashina 2009)], where loan spread is measured as the spread on basis points over LIBOR. ${ }^{11}$ We use the all-in drawn spread (AISD) which measures the interest rate spread plus any associated fees charged to the borrower. ${ }^{12}$ Thus, AISD is an all-inclusive measure of loan price which is expected to depend on borrower, loan and macroeconomic characteristics as well as a variable accounting for the intensity of securitization activity (see below). We estimate the following model:

\footnotetext{
${ }^{11}$ Note that syndicated loans typically carry floating rates that are priced over LIBOR usually in 6 month intervals. Re-pricing is done in relation to changes in LIBOR and the spread remains the same, reflecting the risk of both deal and borrower.

12 See e.g. Sufi (2007), Ivashina (2009), and Bharath et al. (2011).
} 


$$
\begin{aligned}
\text { loan spread }_{i, b, t} & =\beta_{0}+\beta_{1}{\text { Securitization } \text { active }_{b, t}}^{J} \\
& +\sum_{j=1}^{J} \beta_{j} \times \text { Loan terms }_{j, i}+\sum_{h=1}^{H} \beta_{h} \times{\text { Bank } \text { characteristics }_{h, b, t}}^{S-1} \\
& +\sum_{s=1}^{S-1} \beta_{s} \times \text { Loan purpose }_{s, i}+\sum_{k=1}^{K-1} \beta_{k} \times \text { Borrower credit rating }_{k, i} \\
& +\sum_{l=1}^{L-1} \beta_{l} \times \text { Borrower industry }_{l, i}+\sum_{r=1}^{R-1} \beta_{r} \times \text { Tranche rank }_{r, i}+\sum_{y=1}^{Y-1} \beta_{y} \times \text { Year }_{i, y} \\
& +e_{i, b, t}
\end{aligned}
$$

We utilize two set of alternative variables to proxy for the securitization activity of banks:

1. Securitization active takes the value of 1 if a bank securitized any assets in the year when the loan is syndicated and 0 otherwise. This variable measures the immediate impact of bank's securitization activity on loan pricing.

2. We calculate two dummy variables using each bank's level of securitization activity. First, we calculate the relative size (i.e. as a percentage of total assets) of total securitization activity of each bank active in the securitization market between 2000 and 2009. Then we calculate two dummy variables, less active and more active, to classify these banks into two groups. Less active takes the value of 1 if the bank's securitization level is below the median value of all banks' securitization volume and 0 otherwise. More active takes the value of 1 if the bank's securitization level is above the median value of all banks' securitization volume and 0 otherwise.

We account for bank specific characteristics by taking into account banks' size (measured as total assets), capital (measured as the ratio of total equity capital to total assets) and profitability (return on assets). We also control for factors related to the syndicated loan deal characteristics including loan size, maturity, guarantees and collateral. Loan size is measured as the natural logarithm of the syndicated loan's size. Maturity is the duration of the loan in years. Loans with duration shorter than 1 year are classified as short-term while loans with an initial maturity longer than three years are classified as long-term. Guarantee is a dummy variable taking the value of 1 if the loan is guaranteed and 0 otherwise. Collateral is a dummy variable taking the value of 1 if there is any collateral pledged 
for the loan and 0 otherwise. Loan purpose is a set of dummy variables depending on the purpose of the loan which can be classified as: general corporate use, capital structure, project finance, transport finance, corporate control and property finance.

We also account for borrowers' credit quality and its industrial sector via a first set of dummy variables reflecting the median credit rating of the borrower as identified by the three largest credit rating agencies (Moody's, Standard and Poor's and Fitch) at the time of issuance. ${ }^{13}$ Borrower industry is a set of dummy variables related to the business of the borrower (i.e. construction and property, high-tech industry, infrastructure, population related services, state, manufacturing and transport). We also control for the differences in risk existing among the different tranches of a deal (Tranche rank). We create an ordinal variable that ranges from 1 to 10 depending on the seniority of the tranche within the a deal. Following Cumming et al. (2014), we use tranche spreads to proxy for the riskiness of the tranches ( 1 being the least risky) of a deal to rank the tranches. We then use dummy variables to control for each tranche rank. ${ }^{14}$ Finally, we also control for the macro environment including Year dummy variables.

\subsection{Data sources}

We construct our dataset by combining data from three different sources. Securitization data are obtained from Dealogic (Bondware), a private commercial data provider, and completed with private confidential data on securitization activity obtained from Standard and Poor's (S\&P) which allows us to include also private deals. We have manually matched information on deal-by-deal securitization issuance to each euro-area originating bank. ${ }^{15}$ The advantage of using data on securitization activity from Bondware and S\&P is that the name of the originator, date of issuance and deal proceeds are all registered. We include funded ABS securities as well as cash-flow (balance-sheet) CDOs issued by euro-area originating banks.

Data on syndicated loan deals are obtained from Dealogic (Loanware), a commercial database which contains detailed information on syndicated loan contracts. Dealogic provides information on each syndicated loan contract including maturity, loan size, collateral, presence of guarantees, loan

\footnotetext{
${ }^{13}$ We standardize the credit ratings using descriptors of each category provided by rating agencies.

${ }^{14}$ We also considered controlling for tranche risk differences by instrument type of the tranche (such as term loan or credit line), similar to Cerutti et al. (2014), however, we observed that within the same deal tranches that has similar instrument type might have different spreads within the same deal. Therefore we use spread as a more robust indicator for possible tranche differences.

15 To our knowledge the existence of government sponsored agencies complicates the creation of such a database matching securitization origination to individual banks in the United States.
} 
purpose as well as the identification of the borrower and banks involved in the syndicate. The database also indicates the business sector of the borrower and the credit rating attached to the issued instrument. Finally, banks' balance sheet and income statement information are obtained from Bankscope, a commercial database maintained by International Bank Credit Analysis Ltd. (IBCA) and the Brussels-based Bureau van Dijk. Overall the dataset covers 10,911 loan tranches, between 2000 and 2009, lent by 406 broadly similar European banks 94 of which were active in the securitization market during this period. We present a summary descriptive statistics related to the sample in Table 1 Panel A.

Furthermore we expand the database significantly at the individual deal level by identifying those syndicated loan deals that were eventually securitized. This is done by resorting to a unique database constructed by collecting deal-by-deal confidential information from all major European Trustees. This was done for loans issued between 2005 and 2009. Namely, 1,795 out of 4,652 syndicated loans extended during this period are subsequently securitized.

In constructing the dataset, we include, first, all syndicated loans for which the main variables on loan terms and borrower details are present. Second, we extract the reported participant European banks' names that have been involved in these loan syndicates. Syndicated loans' information at the individual deal level is subsequently matched with extensive data on individual banks' characteristics obtained from Bankscope on a yearly basis. For example if Loan $i$ is issued by Bank $X$, Bank $Y$ and Bank Z in 2007 and Loan j is issued by Bank X and Bank $Q$ in 2008 then these combinations of loans and banks are matched as follows:

Loan i's terms and borrower's data for 2007 + Bank X's data for 2006 Loan i's terms and borrower's data for 2007 + Bank Y's data for 2006 Loan i's terms and borrower's data for 2007 + Bank Z's data for 2006 Loan j's terms and borrower's data for 2008 + Bank X's data for 2007 Loan j's terms and borrower's data for 2008 + Bank Q's data for 2007

Overall this process generated 84,926 deal-matched observations. As indicated, as these three data sources do not share a unique identifier, all the data is laboriously matched via the banks' names.

It is important at this point to explain the special features of the syndicated loan market as this may have a potential impact on results in the following section. In a typical syndicated loan two or more banks agree jointly to make a loan to a single borrower. Lead arranger banks are situated at the core of the process by helping out to put together the deal and find participant banks to finance the loan. Participant banks often have an "arm's-length" relationship with the borrower and act through 
the arranger [(Simons 1993); (Sufi 2007)]. Structure of syndicated lending may result in information asymmetries within the lending syndicate between banks of varying degrees of seniority [(Pichler \& Wilhelm 2001); (Lee \& Mullineaux 2004); (Jones et al. 2005); (Sufi 2007); (Focarelli et al. 2008); (Ivashina 2009); (Bharath et al. 2011)]. Hence the composition of the syndicate and the reputation of the arranger may reduce these information asymmetries.

We present the composition of arrangers and participants in our data in Table 1 Panel A. The average number of lead arrangers in a syndicated deal originated in Europe is 3.37 while average number of all arranges, including leads, is 5.22. Number of all lenders is, on average, 10.31 banks. We present the top ten lead and participant banks in Table 1 Panel B. In terms of value of deals, top ten lead arrangers and participant banks contributed to $37 \%$ and $43 \%$ of all tranches in our data. It is worth to note here that the prevalence of lead banks in the European market is less concentrated when compared to the US market. In the US market a handful of commercial and investment banks were involved around 70\% of all syndicated loan deals during the period between 1992 and 2004 (Altunbaş et al. 2006).

We treat each syndicated loan as if consisting of many loans extended independently by each syndicate loan member. This is only an approximation as in reality, all the syndicate members jointly determine the price of the loan. Once the price is set, banks can then decide to enter the deal, or not, as price-takers. Ideally, one would like to have the pricing of all loans in banks' portfolio, including loans lent bilaterally by these banks to all borrowers. As this type of data is not available, following the literature we use information from the syndicated loan market to assess bank behavior (see for instance Benmelech et al., 2012).

It is important also to note that some syndicated loans are tranched. Tranching refers to the number of securities offered as part of the same pool of underlying transactions, with riskier parts of the 'pie' sliced off into different baskets and sold to investors with differing risk appetites (Cumming et al., 2014). In our sample, $44.3 \%$ of the syndicated loans are tranched and the rest, $55.6 \%$, are nontranched deals. Looking at the distribution of tranches by banks is important as the choice of tranche by these banks may influence our results if, for instance, securitization active banks chose riskier tranches. In Panel C of Table 1, we compare the holdings of tranches by different type of banks. Tranche seniority ranks are assigned according to the reported spread (1 being the most senior tranche). We observe that the maximum number of tranches for a deal in our sample is 10 . Nontranched deals are not shown as our focus is examining the behavior of banks when loans are tranched. We find that for tranched deals, $40.3 \%$ of the tranches are ranked as first and $30.1 \%$ as 
second. Only a small number of deals have more four tranches. More importantly for our purposes the differences between less active and more active banks in terms of the distribution of tranches they hold are minimal. For all securitization-active banks, 53.7\% of all the tranches held by less active are first tier, while this ratio is $52.5 \%$ for more active ones. For large banks, more active banks holdings of first tier tranches are $52.5 \%$ compared to $53.6 \%$ by less active large banks. The percentages are even closer for second and third tier tranches. These distributions, suggest that there are only negligible differences in tranche choices between the less and more securitization active banks.

In the next section we present results for the main model presented above. Subsequently, in Section 5, we check robustness of our results controlling for syndicate structure and asymmetric information.

\section{Results}

\subsection{Baseline model}

We run the model presented in section 3.1 that considers the impact of bank securitization activity on the price of syndicated loans and progressively introduce controls for bank characteristics while employing the two different sets of variables accounting for securitization activity separately. We run our estimates with and without banks' fixed effects and re-run the model including clustered errors at the bank level.

Results in Table 2 show that banks active in the securitization market priced loans more aggressively compared to banks that do not securitize their assets. That is we find that securitization active is negatively associated with the loan spread. Being more or less active in the securitization market does not change the signs of the coefficients. Both groups of banks charge lower spreads when compared to banks that are not active in the securitization market. Similarly, controlling for bank characteristics does not change the results while suggesting that loans with shorter maturity and larger size have lower prices. Estimations including bank fixed effects show that within securitizing banks most of the relationship between securitization and pricing of loans takes place for the group of less active banks (i.e. those less active in the securitization market). That is, the group of banks active 
in the securitization market with a relatively low level of activity compared to their peers appears to charge lower spreads compared to non-active banks. ${ }^{16}$

\subsection{Bank size effects}

Next we investigate whether bank size has an influence on pricing. We analyze the size effects by dividing the banks into two main groups defined as large and small. ${ }^{17}$ Results are presented in Table 3. For small banks we do not see that being active in the securitization market has an impact on loan pricing. Similarly, the variables less active and more active are also not relevant for smaller institutions. In other words, for small banks securitization activity does not seem to play a role on loan pricing. In contrast, for larger banks we find a negative relationship between the securitization active variable and loan spreads. Larger banks seem to be charging lower spreads when extending new loans if they are active in the securitization market. This finding would be consistent with the idea that larger banks might be better able to diversify or manage credit risk and could therefore grant credit to borrowers at lower costs. To dig deeper into this issue also in this setting we include the securitization variables accounting for volume of activity. The results for the last two models (also in Table 3) show that particularly for larger banks most of the negative impact of securitization on loan spreads continues to take place for banks that are less active in the securitization market than their peers. ${ }^{18}$

\subsection{The effect of pre-crisis period}

We also consider how banks' pricing behavior due to securitization might change in relation to the business or credit cycles as there is evidence suggesting that lending standards change significantly with macroeconomic conditions (Demyanyk \& Van Hemert 2011). In this respect, it is particularly important to observe bank behavior for the period prior to the recent credit crisis as it has been often advocated that during this period banks increased their risk-taking behavior on many fronts. In particular by lowering their lending standards in the years leading up to the crisis which coincided with

\footnotetext{
16 As a robustness check and to see whether unobserved bank and loan effects influence the results, we run estimations clustering standard errors by bank and loan. Results do not change and remain robust in these models.

17 We group the banks by using the median assets' size.

18 In unreported estimations, we also interact the bank size variable with securitization dummy variables. We do not find these interaction variables to be significant. This is probably because our securitization variable captures the general behavior of banks when they are broadly grouped. We also run an additional regression to compare less and more active large banks by excluding the non-securitizers banks from the sample. We find the coefficient of less active banks to be -11.60 which is statistically significant at $1 \%$ level. This result confirms our main results presented in Table 3 for the whole sample. These results are available upon request.
} 
increases in securitization activity during this period (Maddaloni \& Peydró 2011). We observe bank behavior in the pre-crisis period using a dummy variable, pre-crisis period, which equals 1 for the period ranging from January 2005 to June 2007 and 0 otherwise. To take this analysis one step further, we also interact our pre-crisis dummy with the securitization variables. Results are presented in Table 4.

For all estimations we find an overwhelmingly negative, systematic and strong relationship between the pre-crisis dummy and loan spreads. Banks were charging significantly lower spreads prior to the financial crisis compared to the rest of our sample period of analysis. Surprisingly, none of the interactions between the securitization activity variables and the pre-crisis period seem to be relevant. Again we find that banks less active in securitization charge lower spreads. All these findings are further confirmed when we split our sample across bank sizes (Table 5). The only interesting exception is the significant and negative coefficient for the interaction variable pre-crisis * securitization active, which however loses its significance when we control for bank fixed effects. Overall we do not find any evidence at the bank level linking securitization activity and lending standards measured via the cost of corporate credit in the years prior to the financial crisis ${ }^{19}$.

\subsection{Securitized versus non-securitized loans}

We expand the analysis using an individual deal-by-deal database that is able to select among all syndicated loans, those deals that were eventually securitized. Our objective is to ascertain whether those loans that were securitized were also issued at a lower price than those not securitized. For this latter exercise we have available observations for the loans that were issued between 2005 and 2009 so the number of observations drops compared to the earlier Tables. We estimate the baseline models separately for securitized and non-securitized loans. In other words, in order to avoid self-selection issues we focus on institutions which are already active in the securitization market including only those loans which are securitized. Within those loans and for those institutions we consider whether more activity at the bank level in the securitization market involves a more aggressive pricing of loans.

Results (presented in Table 6 under the label securitized loans) are consistent with previous findings. We do not find significant results for more active banks. Instead, in this setting, we find that

\footnotetext{
${ }^{19}$ In unreported regressions, we also control for borrower country of origin when estimating our models. It seems that borrowers' characteristics capture some cross country differences and residual unobserved country effects have a minimal impact on the coefficients and their significance. These results are available upon request.
} 
banks that are less active in the securitization market were pricing loans at lower spreads. For nonsecuritized loans, we also observe similar results although with larger coefficients.

Table 7 replicates the previous table but focuses on the larger banks. Findings remain valid even for this reduced sample. We find that among banks active in the securitization market, larger institutions making less use of the securitization market charge lower loan prices regardless of whether they are securitized or not. In large banks underpricing is more prevalent for loans which are not securitized and are kept in banks' books. Indeed the coefficient of the variable less active, shows that the negative loan spread due to securitization, decreases from -13.66 basis points to -23.37 basis points for those loans that are not-securitized.

We then examine the impact of pre-crisis period on loan pricing only for the larger institutions by utilizing pre-crisis dummies and interaction variables. The results presented in Table 8 show that for securitized loans the significance of variable less active weakens and the pre-crisis dummy variable continues to be negatively related to loan price. We find that the interaction variables pre-crisis * less active and pre-crisis * more active are not significant for securitized loans.

One interesting finding regards the estimations for the non-securitized loan sample which shows a strong negative relationship between less active and loan spread and a weaker, but still significant, coefficient for more active. More importantly we observe a larger (and significant) coefficient for pre-crisis period dummy variable. The interaction variable pre-crisis period * less active is also significant. Although it is reported to be positive, the impact of the interaction variable on the dependent variable should be interpreted by combining the coefficients of variables pre-crisis period, less active and pre-crisis period * less active [for the most controlled estimations this would be $(-30.70)+(-111.85)+(23.71)=(-118.84)]$. The interaction variable amplifies the impact of securitization activity on the loan price of non-securitized loans during the buildup period before the 2007-2009 financial crisis.

Results indicate that loans that are not securitized and kept on the originating banks' books seem to be priced more aggressively, after controlling for all other factors that are affecting the spread, than those securitized. In other words, this potential under-pricing signals that these non-securitized loans, which are otherwise very similar to securitized loans, are riskier. This is partly in line with the signaling literature which suggests that banks might have an incentive to retain lower quality loans and package and sell off to investors better quality ones. [(Greenbaum \& Thakor 1987); (DeMarzo 2005); 
(Instefjord 2005)]. ${ }^{20}$ Another possibility is that banks are no more skilled than the financial markets in assessing the credit quality of borrowers as loans kept in the originating banks' books seem to have been underpriced by more. ${ }^{21}$

Overall, we find only somewhat suggestive microeconomic evidence that securitization had an impact on lending standards as measured by the adjusted cost of corporate credit on the syndicated loan market. This stands in contrast with evidence for the for the United States on the mortgage (see for instance Mian \& Sufi 2009) or the corporate credit markets (see Nadauld \& Weisbach 2012). It is however in line with recent evidence that suggests that adverse selection problems in loan securitizations may be less severe than commonly believed [(Benmelech et al. 2012); (Albertazzi et al. 2015)].

We do, however, find some limited evidence pointing towards more aggressive pricing for large banks that are relatively less active in the securitization market. This evidence is broadly in line with findings by Instefjord (2005) and Haensel and Krahnen (2007). Tentatively one possible explanation for these latter results might be related to reputational factors. Namely, for banks that are more active in the securitization market and are regularly originating credit to be securitized, their continuity in terms of their fee income (and overall business model) might depend, to a large extent, on maintaining the quality of the assets underlying these deals. Hence in order to preserve their reputational capital they might be less likely to be aggressive risk takers by underpricing those loans that are to be securitized [(Kawai 2014); (Hartman-Glaser 2011)]. In contrast, banks which are less dependent on the securitization market might have a more opportunistic behavior. They might price credit risk more aggressively particularly during periods with lower credit risk aversion at the macroeconomic level in which there might be stronger investors' demand for securitized assets.

Overall our results overwhelmingly suggest that the remarkable increase in price aggressiveness in the syndicated loan market in the run up to the 2007-2009 crisis seems to be mostly driven by macroeconomic factors rather than by the extent or degree of participation in the securitization market by individual banks. That is, we do not find that banks, relying more strongly on securitization for funding purposes, lowered their lending standards more aggressively than their peers during this period. Results at the loan level complement and support our earlier findings. Securitized

\footnotetext{
20 Overall, the discrepancy in lending standards among securitized and non-securitized loans can arise if there are "unsuspecting" investors unable to fully evaluate the credit quality ex-ante (Gennaioli et al. 2012). It could also possible that the investors investing in securitized assets have an incentive to herd even if the interest rates on the securitized assets differ from their fundamentals (Shleifer \& Vishny 1997).

21 In unreported results, we also run our regressions controlling for country of the origin of the borrower. Results suggest that differences between estimations with and without country effects are small and our results do not change. It seems that our use of an extended set of dummy variables accounting for borrowers' credit rating and industry might result in a low impact by the country dummy variables.
} 
loans sold to other investors through CLOs originated by banks which are more active in the securitization market are not priced more aggressively than those originated by banks which are less active users of the securitization market for funding purposes.

\section{Robustness checks}

\subsection{Accounting for information asymmetries in loan syndications}

Bank characteristics may influence loan pricing. Accordingly, the majority of the papers in the literature use the characteristics of the lead bank to control for these effects [(Lee \& Mullineaux 2004); (Jones et al. 2005); (Sufi 2007); (Focarelli et al. 2008); (Ivashina 2009); (Bharath et al. 2011)]. An important disadvantage of the existing literature is that it typically includes the characteristics of the lead bank only. This is a main limitation, given that syndicated lending is a joint decision of all participating banks. In fact, there is evidence suggesting that the characteristics of other members matter significantly on the conditions of credit (Gadanecz et al. 2012). For this reason in the regressions presented above we included the financial characteristics of the participant banks to account for individual bank behavior.

At the same time a crucial determinant of the decision to join a syndicate may be asymmetries of information. A bank's decision to participate on a particular syndicate may be influenced by the opacity of the borrower. Hence, our results may be driven by the existence of omitted variables due to asymmetric information in the formation of loan syndicates. More specifically, banks that are more active in the securitization market may also be more sophisticated and better informed. As a result, they might be more likely to be arrangers in loan syndicates. These may face lower informational asymmetries than smaller banks that are less active in securitization. Hence, smaller banks may only choose to participate in loans with less informational asymmetries which have as a result also a lower

price. We cannot ex-ante exclude that this self section bias into securitization due to asymmetries of information by certain banks could be driving our main results.

To reduce the possible impact of this bias, we run our models for a limited sample in which we include only those observations where the lender has previously lent to a borrower in previous years. In other words, we exclude the observations where a lender and borrower are matched for the 
first time in our sample. ${ }^{22}$ We conjecture that previous bank-borrower relationships, i.e. repeat lending, will minimize the opacity of the borrower in the current deal and reduce the information asymmetries for participant lenders.

Following Sufi (2007) we also control for syndicate size (number of lenders) as an extra proxy to measure the opacity of the borrower. As Sufi (2007) shows smaller loan syndicates signals an increase in borrower's opacity. In addition, we control for the possible fixed effects of major lead banks. The presence of some of these banks in the deal may influence the loan price as more reputable banks might reduce information asymmetries. We identified 75 groups of top 20 lead banks that often participate into loan syndications alone or collectively in the European market.

We present the results estimated for the selected main models in Table 9. Our key findings do not change, even though we constraint the sample to a limited number of deals. Securitization activity coefficients for smaller banks are not significant. Larger banks with low level of securitization activity charge lower spreads as we report significant coefficients for less active only. We also run the analysis for securitized versus non-securitized loans (presented in last two columns of Table 9). Unlike in our earlier findings, the results do not show any significant pricing difference between securitized and non-securitized loans. ${ }^{23}$

\subsection{Syndicate level analysis}

In our analysis we treat each loan as if it is lent by a single syndicate member because we aim to measure the behavior of individual banks. Our approach may have the shortcoming of not capturing some of the possible effects of the group (syndicate) decision on the loan price even though we attempt to control for syndicate characteristics with various variables. ${ }^{24}$ Hence, we re-run the analysis at syndicate level to test robustness of our results. We construct a number of variables that aim to capture the securitization activity levels of banks within the syndicate as a group. Securitization active bank ratio equals to the number of securitization active banks to total banks in the syndicate. Less active syndicate is ratio of less active banks to total banks in the syndicate. More active

\footnotetext{
22 Note that a limitation of this procedure is that we do not observe the lender borrower relationship for the pre-sample period before 2000.

23 Another potential source of selection bias might be related to a more general lending decision. In our sample we only observe those banks that choose to lend via syndicated loan market. However, other banks may not regard syndicated lending as an option or may not have access to this market. This may signal a potential sample selection problem where only banks with certain characteristics may participate in syndicates. As another robustness check we estimate a selection equation using a pool of 5,546 European banks of which only 406 are in our original sample. We use a Heckman's two-step procedure and run a selection equation to estimate the probability of a bank participating in syndicated loan market. We then estimate our main models by including the inverse of Mill's ratio derived from the first step. Our main findings still hold consistently with estimates adjusted for selection. This specification also supports our earlier results that non-securitized loans are priced lower. These results are available upon request.

${ }^{24}$ This approach is an outcome of a general limitation that other papers are also exposed to due to limitations of unavailability of proprietary bank loans data. Often syndicated loans are used to observe bank lending behavior because syndicated lending data is publicly available.
} 
syndicate is ratio of more active banks to total banks in the syndicate. We also account for borrower opacity using an aggregate variable for syndicate members past relationship with the borrower. Accordingly, previous relationships equals to the number of banks that lend to the same borrower in the past to the total number of banks in the syndicate. For bank characteristics we calculate one set of indicators representing the syndicate by utilizing the average values of all banks' total assets, equity to total assets and return on assets. We also control for syndicate size and syndicate fixed effects to capture the composition of the syndicate.

We present results in Table 10. The estimations of the main models for the tranche level aggregate data are shown in the first two columns. We find that there is a positive and a significant relationship between the number of securitization active banks in the syndicate and loan price (Column I). This coefficient seems to be driven by the less active banks in the syndicate (Column II). Subsequently in Columns III and IV, we present results for the deal level sample, which includes only those deals that are not tranched. ${ }^{25}$ We find the same results with slightly larger coefficients. In Columns V to VIII we distinguish between securitized and non-securitized loans for the 2005-2009 periods. We find that securitization activity leads to lower spread in non-securitized loans. ${ }^{26}$

\subsection{Deal level analysis with only non-tranched deals}

Most of our results are obtained at the tranche level as this allows us to utilize a more comprehensive sample. Even though tranches are regarded as independent loans within a deal, different tranches may influence the overall pricing of the deal. Furthermore, banks may be interested in participating only in certain tranches of the deals. These two factors may have an influence on our results. To check for the robustness of our results for such an impact, we re-estimate our main models with a restricted sample that includes only those deals that are non-tranched (i.e., deals where we only observe one instrument for a given Dealogic deal number). Results, presented in Table 11, are similar, if not stronger, compared to our main estimations.

\footnotetext{
25 This limited sample provides further robustness checks for consistency of our results.

26 There may also be potentially a selection issue for our deal level analysis since we include variables for the syndicate members average securitization activity. This average depends on each syndicate member's decision to be in a particular syndicate. It is not possible to control for this type of bias which we believe would have a minimal effect to our main findings given the similar results we presented in a number of robustness checks. We acknowledge the limitations to our approach in terms of lingering selection biases. We believe the use syndicate level fixed effects may control partially for this potential bias.
} 


\section{Conclusion}

Securitization has been under intense scrutiny for potentially fuelling credit growth by lowering credit standards thereby endangering financial stability [(Shin 2009); (Farhi \& Tirole 2012); (Financial Crisis Inquiry Commission 2011)]. We explore the nexus between securitization and lending by examining the pricing of new loans by European banks. We pursue two complementary approaches that include comprehensive information at the level of individual banks and of deals. We construct a wide sample of 84,926 matched bank-loan observations that allows us to control for lender, borrower and loan characteristics. In addition, a unique feature of our dataset is that we can identify those individual syndicated loan deals that were eventually securitized.

We do not find that banks active in the securitization market were pricing loans more aggressively than other institutions. We do find, however, that large banks that make use of the securitization market but are relatively less active in this market than their peers may charge lower spreads when extending new loans. Our results are robust at tranche, syndicate and deal level analysis including the impact of possible selection bias issues and structure of loan syndicates.

Probably more importantly, our findings also show that in the run up to the 2007-2009 financial crisis banks relying on securitization did not lower their lending standards much more aggressively than other institutions. That is, banks, making use of the securitization market for funding purposes, did not lower the cost on credit in the syndicated loan market more than their peers during this period. The results at the loan level complement and support these findings. Securitized loans originated by banks which are more active in the securitization market are not priced more aggressively than those originated by banks which are less active users of the securitization market for funding purposes.

From a policy perspective, it is important to underline that from our results one cannot affirm that securitization did not have a significant impact on financial stability during the period we study. The message is rather that we need a more nuanced understanding, and certainly more data, on whether and how securitization could lead to additional risk-taking by banks. It could be that securitization has an indirect impact on financial stability. For instance secularization might have the potential to influence in a substantial manner the overall credit cycle. From our data we would not be able to test this latter hypothesis as the large increases in securitization activity in most European countries might have contributed in amplifying the credit cycle in a manner not fully identifiable at the 
microeconomic level. From a policy perspective our results seem to support the introduction of macro prudential policies aimed at smoothing the credit cycle. Hence, regulatory actions that aim to improve the incentive structure in the securitization process probably would need to incorporate the impact of the state of the credit cycle as well. 
Table 1

\begin{tabular}{|c|c|c|c|c|c|c|c|c|}
\hline \multicolumn{5}{|c|}{ Panel A: Descriptive statistics ${ }^{1}$} & \multicolumn{4}{|c|}{ Panel B: Top lead and participant banks } \\
\hline Bank characteristics & No of banks & Mean & Median & Std. dev. & \multicolumn{4}{|c|}{ Lead banks } \\
\hline All banks & & & & & By number of deals & $\%$ & $\begin{array}{c}\text { By value of } \\
\text { deals }\end{array}$ & $\%$ \\
\hline Total assets & 406 & 116,512 & 12,717 & 322,460 & BNP Paribas & 6.1 & BNP Paribas & 5.6 \\
\hline Equity capital to total assets & 406 & 8.41 & 6.56 & 9.31 & Société Générale & 4.3 & Royal Bank of Scotland & 4.7 \\
\hline Return on assets & 406 & 0.64 & 0.56 & 1.14 & Royal Bank of Scotland & 4.1 & Société Générale & 4.4 \\
\hline Securitization active banks & & & & & Credit Agricole & 3.1 & Citigroup & 3.9 \\
\hline Total assets & 94 & 173,628 & 31,179 & 368,487 & BBVA & 3.1 & JP Morgan & 3.5 \\
\hline Equity capital to total assets & 94 & 7.12 & 6.41 & 6.12 & Natixis & 2.5 & Credit Agricole & 3.3 \\
\hline Return on assets & 94 & 0.71 & 0.63 & 1.34 & ING & 2.3 & Deutsche Bank & 3.1 \\
\hline Securitization non-active banks & & & & & Santander & 2.2 & Barclays Capital & 2.9 \\
\hline Total assets & 312 & 79,043 & 6,830 & 300,634 & Commerzbank Group & 2.2 & HSBC & 2.8 \\
\hline Equity capital to total assets & 312 & 9.56 & 6.77 & 11.43 & Intesa & 2.1 & BBVA & 2.7 \\
\hline Return on assets & 312 & 0.61 & 0.51 & 1.25 & & & & \\
\hline Loan characteristics & No of loans & Mean & Median & Std. dev & \multicolumn{4}{|c|}{ Participant banks } \\
\hline Spread & 10,911 & 202 & 100 & 167 & By number of deals & $\%$ & deals & $\%$ \\
\hline Loan amount & 10,911 & 287 & 165 & 958 & BNP Paribas & 7.2 & BNP Paribas & 6.9 \\
\hline Maturity & 10,911 & 6.1 & 5 & 3.9 & Credit Agricole & 5.6 & Commerzbank & 5.0 \\
\hline Collateral & 10,911 & 0.31 & 0 & 0.46 & Natixis & 5.1 & Credit Agricole & 4.6 \\
\hline Guaranteed & 10,911 & 0.01 & 0 & 0.11 & UniCredit & 4.6 & Royal Bank of Scotland & 4.5 \\
\hline Syndicate composition & No of loans & Mean & Median & Std. dev & Société Générale & 3.9 & UniCredit & 4.5 \\
\hline Number of lead arrangers & 10,911 & 3.37 & 2 & 4.41 & Commerzbank & 3.9 & Natixis & 3.9 \\
\hline Number of all arrangers & 10,911 & 5.22 & 3 & 5.17 & Royal Bank of Scotland & 3.4 & Deutsche Bank & 3.6 \\
\hline Number of all lending banks & 10,911 & 10.31 & 8 & 8.58 & Intesa & 2.8 & Société Générale & 3.4 \\
\hline Securitization active (\% of total) & 10,911 & 0.64 & 0.65 & 0.23 & Santander & 2.7 & Citigroup & 3.3 \\
\hline & & & & & Bayerische Landesbank & 2.3 & Intesa & 3.3 \\
\hline
\end{tabular}

Panel C: Tranche distribution by rank and bank participation (excludes non-tranched deals)

\begin{tabular}{|c|c|c|c|c|c|c|c|c|c|}
\hline & & & & \multicolumn{6}{|c|}{ Tranche rank } \\
\hline & & & & 1 & 2 & 3 & 4 & 5 & $5+$ \\
\hline \multicolumn{4}{|c|}{ Distribution of all tranches in the sample (\%) } & 40.3 & 30.1 & 16.3 & 8.5 & 3.3 & 1.5 \\
\hline \multirow{8}{*}{$\begin{array}{l}\text { Bank tranche participation (\% of } \\
\text { tranches held by the given group } \\
\text { in comparison to the groups all } \\
\text { holdings) }\end{array}$} & \multirow{2}{*}{\multicolumn{2}{|c|}{ All banks }} & Non-active & 52.0 & 25.5 & 12.2 & 6.6 & 2.5 & 1.1 \\
\hline & & & Active & 53.0 & 26.1 & 11.4 & 6.1 & 2.4 & 1.0 \\
\hline & \multirow{6}{*}{$\begin{array}{l}\text { Securitization } \\
\text { active banks } \\
\text { only }\end{array}$} & \multirow{2}{*}{ All banks } & Less active & 53.7 & 26.1 & 11.1 & 6.1 & 2.2 & 0.9 \\
\hline & & & More active & 52.5 & 26.0 & 11.6 & 6.2 & 2.6 & 1.1 \\
\hline & & \multirow{2}{*}{ Small banks } & Less active & 53.8 & 25.1 & 11.3 & 6.3 & 2.3 & 1.3 \\
\hline & & & More active & 53.0 & 27.0 & 10.2 & 5.9 & 2.8 & 1.1 \\
\hline & & \multirow{2}{*}{ Large banks } & Less active & 53.6 & 26.3 & 11.1 & 6.0 & 2.2 & 0.8 \\
\hline & & & More active & 52.5 & 26.0 & 11.7 & 6.2 & 2.5 & 1.2 \\
\hline
\end{tabular}

\footnotetext{
${ }^{1}$ Total assets is in million EUR. Spread is measured as basis points over LIBOR. Maturity is in years.

${ }^{2} 55.6 \%$ of the deals are non-tranched.
} 
Table 2

The impact of banks' securitization activity on loan price

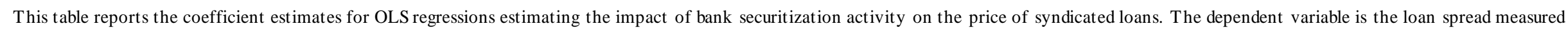

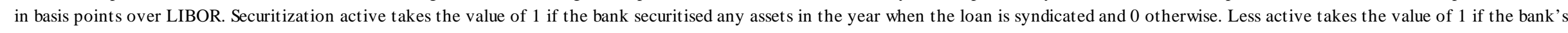

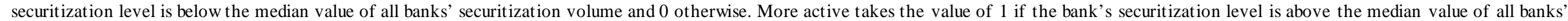

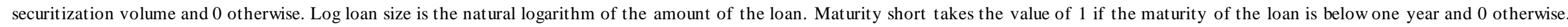

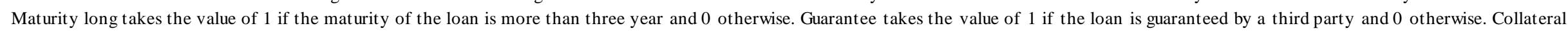

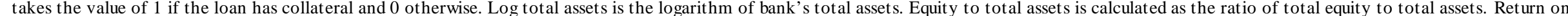

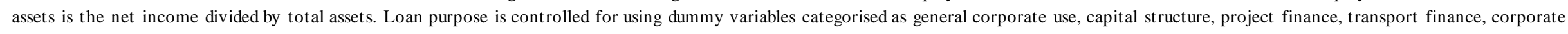

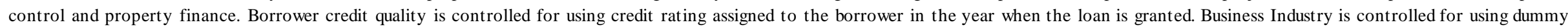

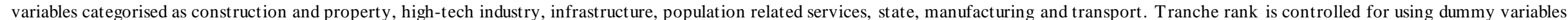

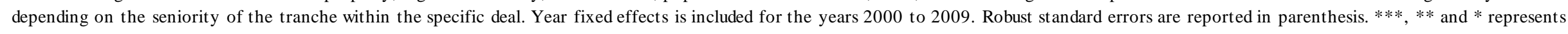
significance levels at $1 \%, 5 \%$ and $10 \%$, respectively.

\begin{tabular}{|c|c|c|c|c|c|c|c|c|c|c|c|}
\hline \multirow[b]{3}{*}{ Securitization active } & \multicolumn{4}{|c|}{ OLS } & \multicolumn{7}{|c|}{ OLS with bank fixed effects } \\
\hline & (I) & (II) & \multirow{2}{*}{$\begin{array}{c}\text { (III) } \\
-2.70 * * *(0.80)\end{array}$} & $(\mathrm{IV})$ & $(\mathrm{V})$ & \multicolumn{2}{|c|}{$(\mathrm{VI})$} & \multicolumn{2}{|c|}{ (VII) } & \multicolumn{2}{|c|}{$(\mathrm{VIII})$} \\
\hline & $-5.56 * * *(0.75)$ & & & & $-9.37 * \quad(4.88)$ & & & $-10.06^{* *}$ & $(4.71)$ & & \\
\hline Less active & & $-6.83 * * *(0.92)$ & & $-4.79 * * *(0.93)$ & & $-11.12^{* *}$ & $(4.27)$ & & & $-12.67 * * *$ & $(4.86)$ \\
\hline More active & & $-4.41 * * *(0.91)$ & & $-0.55 \quad(0.98)$ & & -5.94 & (7.73) & & & -4.91 & (6.54) \\
\hline \multicolumn{12}{|l|}{ Loan characteristics } \\
\hline Log loan size & $-8.47 * * *(0.26)$ & $-8.47 * * *(0.26)$ & $-8.52 * * *(0.26)$ & $-8.53 * * *(0.26)$ & $-9.24 * * *(0.88)$ & $-9.24 * * *$ & $(0.89)$ & $-9.16 * * *$ & $(0.91)$ & $-9.15 * * *$ & $(0.91)$ \\
\hline Maturity short & $-20.8 * * *(1.39)$ & $-20.8^{* * *}(1.39)$ & $-20.90 * * *(1.39)$ & $-20.86 * * *(1.39)$ & $-22.31 * * *(2.26)$ & $-22.24 * * *$ & $(2.28)$ & $-21.65 * * *$ & $(2.25)$ & $-21.52 * * *$ & $(2.28)$ \\
\hline Maturity long & $-7.21 * * *(1.03)$ & $-7.22 * * *(1.03)$ & $-7.03 * * *(1.02)$ & $-7.05 * * *(1.02)$ & $-6.79 * * *(1.83)$ & $-6.80 * * *$ & (1.83) & $-5.51 * * *$ & $(1.79)$ & $-5.50 * * *$ & $(1.81)$ \\
\hline Guarantee & $-10.32 * * *(2.82)$ & $-10.30 * * *(2.82)$ & $-10.11 * * *(2.83)$ & $-10.06 * * *(2.83)$ & $-12.19 * * *(4.52)$ & $-12.20 * * *$ & $(4.50)$ & $-13.35 * * *$ & $(4.42)$ & $-13.39 * * *$ & (4.37) \\
\hline Collateral & $-2.50 * * \quad(1.05)$ & $-2.51 * * *(1.05)$ & $-2.83 * * \quad(1.05)$ & $-2.86 * * *(1.05)$ & $-2.92 \quad(2.65)$ & -2.92 & (2.65) & -2.42 & (2.66) & -2.41 & (2.66) \\
\hline \multicolumn{12}{|l|}{ Bank characteristics } \\
\hline Log total assets & & & $-1.36 * * *(0.23)$ & $-1.46 * * *(0.23)$ & & & & $23.65 * * *$ & $(6.03)$ & $24.54 * * *$ & (5.99) \\
\hline Equity to total assets & & & $0.47 * * *(0.07)$ & $0.46 * * *(0.07)$ & & & & $1.12 * *$ & $(0.46)$ & $1.16^{* *}$ & $(0.47)$ \\
\hline Return on assets & & & $-2.12 * * *(0.41)$ & $-1.46 * * *(0.23)$ & & & & -3.31 & (3.95) & -3.18 & (3.96) \\
\hline \multicolumn{12}{|l|}{ Control for: } \\
\hline Loan purpose & Yes & Yes & Yes & Yes & Yes & Yes & & $\mathrm{Ye}$ & & Yes & \\
\hline Borrower credit rating & Yes & Yes & Yes & Yes & Yes & Yes & & $\mathrm{Ye}$ & & Yes & \\
\hline Borrower industry & Yes & Yes & Yes & Yes & Yes & Yes & & $\mathrm{Ye}$ & & Yes & \\
\hline Tranche rank & Yes & Yes & Yes & Yes & Yes & Yes & & $\mathrm{Ye}$ & & Yes & \\
\hline Year & Yes & Yes & Yes & Yes & Yes & Yes & & $\mathrm{Ye}$ & & Yes & \\
\hline R-square & 0.31 & 0.32 & 0.31 & 0.31 & & & & & & & \\
\hline F-test (p-values) & 0.000 & 0.000 & 0.000 & 0.000 & 0.000 & 0.00 & & 0.0 & & 0.000 & \\
\hline Number of observations & 84,926 & 84,926 & 84926 & 84926 & 84926 & 8492 & & 849 & & 8492 & \\
\hline Number of groups & & & & & 406 & 406 & & 40 & & 406 & \\
\hline
\end{tabular}




\section{Table 3}

Bank size and the impact of banks' securitization activity on loan price

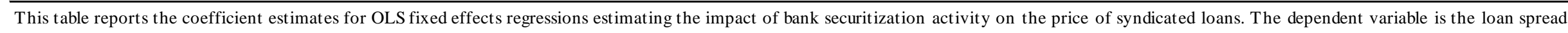

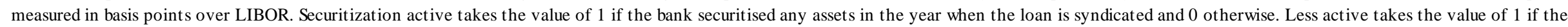

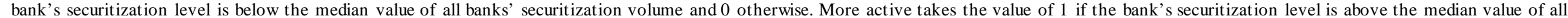

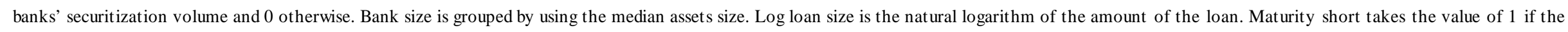

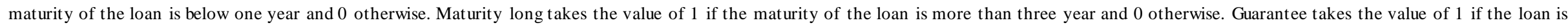

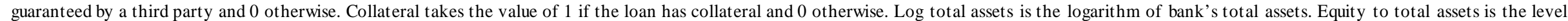

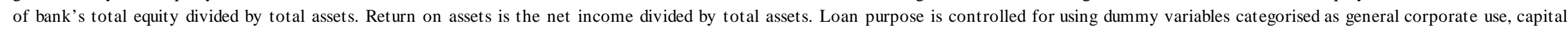

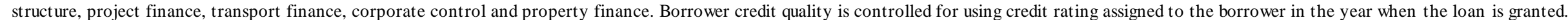

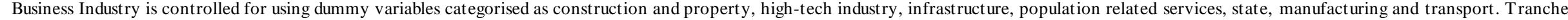

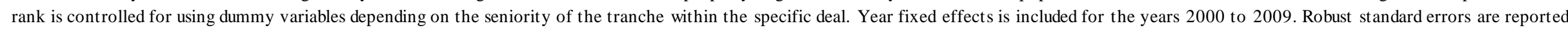
in parenthesis. ***, ** and * represents significance levels at $1 \%, 5 \%$ and $10 \%$, respectively.

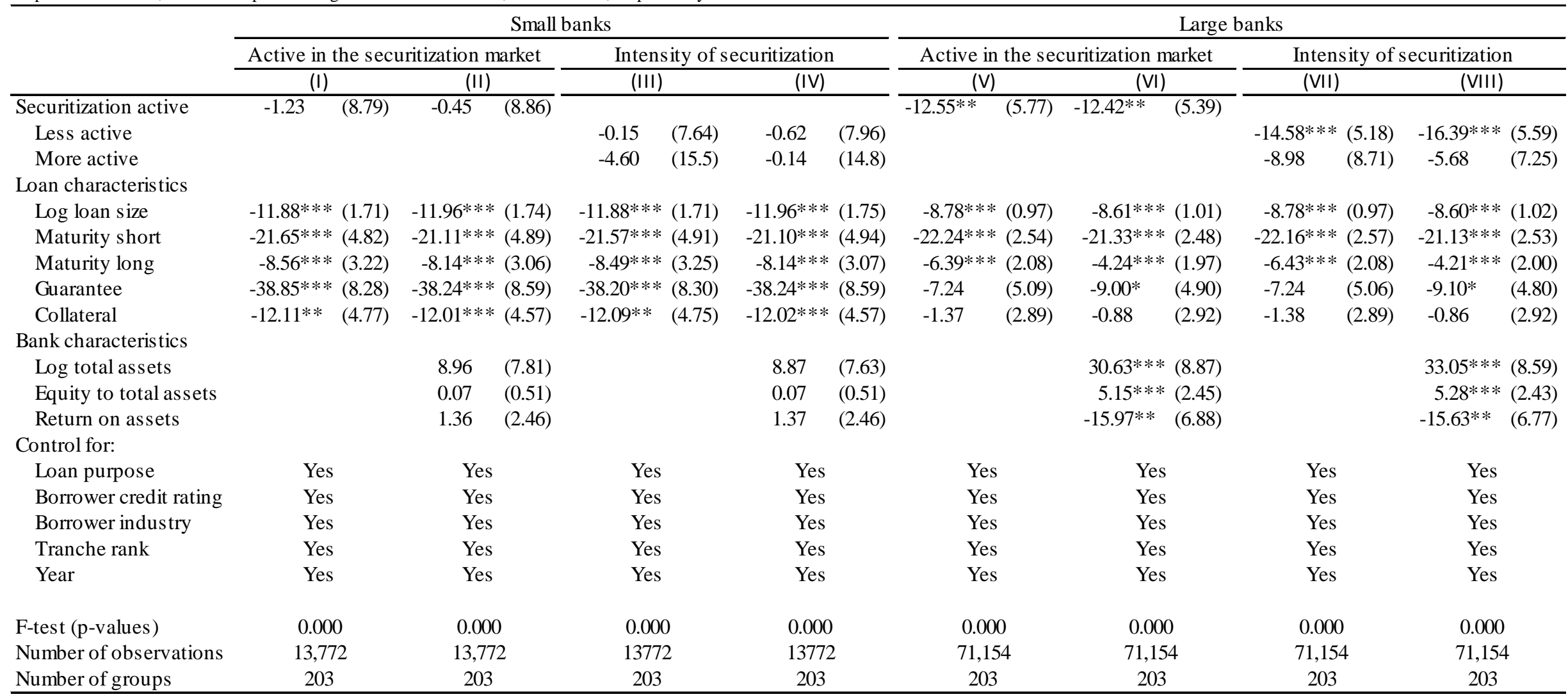




\section{Table 4}

Pre-crisis bank securitization activity and loan price

This table reports the coefficient estimates for OLS fixed effects regressions estimating the impact of bank securitization activity on the price of syndicated loans. The dependent variable is the loan spread measured in basis points over LIBOR. Securitization active takes the value of 1 if the bank securitised any assets in the year when the loan is syndicated and 0 otherwise. Less active takes the value of 1 if the bank's securitization level is below the median value of all banks' securitization volume and 0 otherwise. More active takes the value of 1 if the bank's securitization level is above the median value of all banks' securitization volume and 0 otherwise. Log loan size is the natural logarithm of the amount of the loan. Pre-crisis period takes the value of 1 for the loans issued in 2005 , 2006 and the first six months of 2007 and 0 otherwise. Maturity short takes the value of 1 if the maturity of the loan is below one year and 0 otherwise. Maturity long takes the value of 1 if the maturity of the loan is more than three year and 0 otherwise. Guarantee takes the value of 1 if the loan is guaranteed by a third party and 0 otherwise. Collateral takes the value of 1 if the loan has collateral and 0 otherwise. Log total assets is the logarithm of bank's total assets. Equity to total assets is the level of bank's total equity divided by total assets. Return on assets is the net income divided by total assets. Loan purpose is controlled for using dummy variables categorised as general corporate use, capital structure, project finance, transport finance, corporate control and property finance. Borrower credit quality is controlled for using credit rating assigned to the borrower in the year when the loan is granted. Business Industry is controlled for using dummy variables categorised as construction and property, high-tech industry, infrastructure, population related services, state, manufacturing and transport. Tranche rank is controlled for using dummy variables depending on the seniority of the tranche within the specific deal. Year fixed effects is included for the years 2000-2004 and 2008-2009. Robust standard errors are reported in parenthesis. $* * *, * *$ and * represents significance levels at $1 \%, 5 \%$ and $10 \%$, respectively.

\begin{tabular}{|c|c|c|c|c|c|c|c|c|c|c|c|c|c|c|c|c|}
\hline \multirow[b]{3}{*}{ Securitization active } & \multicolumn{8}{|c|}{ Active in the securitization market } & \multicolumn{8}{|c|}{ Intensity of securitization } \\
\hline & \multicolumn{2}{|l|}{$(1)$} & \multicolumn{2}{|c|}{ (II) } & \multicolumn{2}{|c|}{ (III) } & \multicolumn{2}{|l|}{ (IV) } & \multicolumn{2}{|c|}{$(\mathrm{V})$} & \multicolumn{2}{|c|}{$(\mathrm{VI})$} & \multicolumn{2}{|l|}{ (VII) } & \multicolumn{2}{|c|}{ (VIII) } \\
\hline & $-6.05 * *$ & $(2.71)$ & $-6.35 * *$ & $(2.75)$ & -4.62 & $(3.05)$ & -4.98 & $(3.22)$ & & & & & & & & \\
\hline Less active & & & & & & & & & $-7.15 * * *$ & $(2.55)$ & $-7.80 * * *$ & $(2.79)$ & $-6.53 * *$ & (2.93) & $-7.45 * *$ & $(3.07)$ \\
\hline More active & & & & & & & & & -3.91 & $(4.10)$ & -3.61 & (3.82) & -0.76 & $(4.45)$ & -0.25 & (4.22) \\
\hline Pre-crisis period & $-74.48 * * *$ & $(2.77)$ & $-72.31 * * *$ & $(2.97)$ & $-72.62 * * *$ & $(3.37)$ & $-70.57 * * *$ & $(3.79)$ & $-74.39 * * *$ & $(2.79)$ & $-72.07 * * *$ & (3.03) & $-71.79 * * *$ & $(3.44)$ & $-69.36 * * *$ & $(3.92)$ \\
\hline Pre-cris is period $*$ securitization active & & & & & -3.60 & (3.98) & -3.41 & $(4.38)$ & & & & & & & & \\
\hline Pre-cris is period $*$ less active & & & & & & & & & & & & & -2.41 & $(4.06)$ & -1.84 & $(4.36)$ \\
\hline Pre-cris is period $*$ more active & & & & & & & & & & & & & -6.34 & $(5.18)$ & -6.81 & (5.66) \\
\hline \multicolumn{17}{|l|}{ Loan characteristics } \\
\hline Log loan size & $-8.50 * * *$ & $(0.96)$ & $-8.49 * * *$ & $(0.96)$ & $-8.50 * * *$ & $(0.96)$ & $-8.49 * * *$ & $(0.96)$ & $-8.50 * * *$ & $(0.96)$ & $-8.49 * * *$ & $(0.96)$ & $-8.49 * * *$ & $(0.96)$ & $-8.49 * * *$ & $(0.97)$ \\
\hline Maturity short & $-20.44 * * *$ & $(1.94)$ & $-20.27 * * *$ & $=(1.95)$ & $-20.45^{* * *}$ & $(1.95)$ & $-20.28 * * *$ & $(1.95)$ & $-20.40 * * *$ & $(1.95)$ & $-20.20 * * *$ & $(1.96)$ & $-20.42 * * *$ & $(1.96)$ & $-20.23 * * *$ & $(1.97)$ \\
\hline Maturity long & -0.52 & $(1.43)$ & -0.25 & $(1.43)$ & -0.49 & $(1.42)$ & -0.23 & $(1.42)$ & -0.54 & $(1.42)$ & -0.26 & $(1.43)$ & -0.51 & $(1.43)$ & -0.23 & $(1.42)$ \\
\hline Guarantee & $-16.00 * * *$ & $(3.86)$ & $-16.31 * * *$ & $=(3.86)$ & $-15.95 * * *$ & $(3.85)$ & $-16.26^{* * *}$ & $(3.84)$ & $-16.00 * * *$ & $(3.85)$ & $-16.32 * * *$ & (3.84) & $-15.93 * * *$ & (3.84) & $-16.26^{* * *}$ & (3.83) \\
\hline Collateral & -1.10 & $(2.65)$ & -0.97 & $(2.65)$ & -1.08 & $(2.66)$ & -0.95 & $(2.65)$ & -1.10 & $(2.65)$ & -0.97 & $(2.65)$ & -1.07 & (2.66) & -0.93 & (2.66) \\
\hline \multicolumn{17}{|l|}{ Bank characteristics } \\
\hline Log total assets & & & $8.12 * *$ & $(3.55)$ & & & $8.01^{* *}$ & (3.65) & & & $8.65^{* *}$ & (3.54) & & & $8.89 * *$ & (3.65) \\
\hline Equity to total assets & & & 0.47 & $(0.29)$ & & & 0.47 & $(0.29)$ & & & 0.49 & $(0.29)$ & & & 0.50 & $(0.29)$ \\
\hline Return on assets & & & -1.58 & (2.39) & & & -1.61 & (2.38) & & & -1.52 & $(2.40)$ & & & -1.49 & $(2.41)$ \\
\hline \multicolumn{17}{|l|}{ Control for: } \\
\hline Loan purpose & Yes & & $\mathrm{Ye}$ & es & Yes & & Yes & & Yes & & Yes & & Yes & & Yes & \\
\hline Borrower credit rating & Yes & & $\mathrm{Ye}$ & & Yes & & Yes & & Yes & & Yes & & Yes & & Yes & \\
\hline Borrower industry & Yes & & $\mathrm{Ye}$ & & Yes & & Yes & & Yes & & Yes & & Yes & & Yes & \\
\hline Tranche rank & Yes & & $\mathrm{Ye}$ & & Yes & & Yes & & Yes & & Yes & & Yes & & Yes & \\
\hline Year & Yes & & $\mathrm{Ye}$ & & Yes & & Yes & & Yes & & Yes & & Yes & & Yes & \\
\hline F-test (p-values) & 0.00 & & 0.0 & 00 & 0.000 & & 0.000 & & 0.00 & & 0.000 & & 0.000 & & 0.000 & \\
\hline Number of observations & 84,92 & & $84, \mathrm{c}$ & 926 & 84,92 & & 84,92 & & 84,92 & & 84,92 & & 84,92 & & 84,92 & \\
\hline Number of groups & 406 & & 40 & 06 & 406 & & 406 & & 406 & & 406 & & 406 & & 406 & \\
\hline
\end{tabular}




\section{Table 5}

Bank size and the impact of securitization activity on loan price during the pre-crisis period

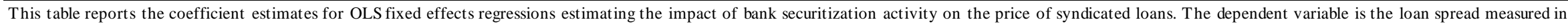

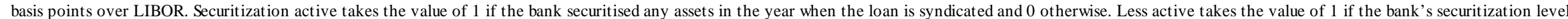

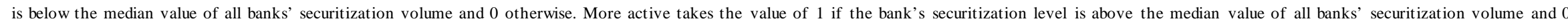

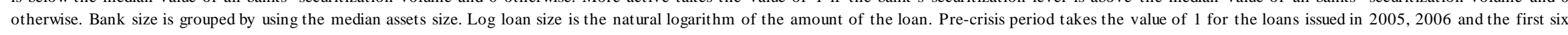
months of 2007 and 0 otherwise. Maturity short takes the value of 1 if the maturity of the loan is below one year and 0 otherwise. Maturity long takes the value of 1 if the maturity of the loan is more than three year

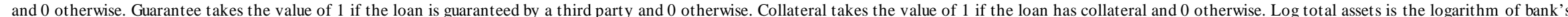

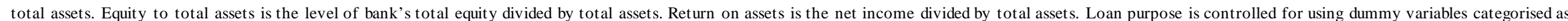

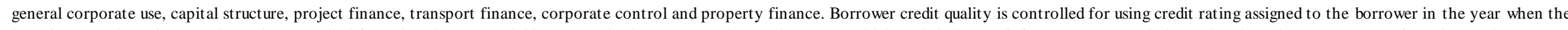

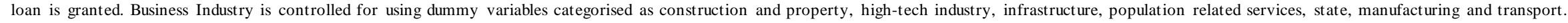

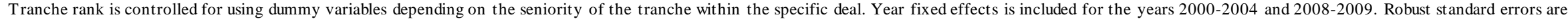
reported in parenthesis. $* * *, * *$ and $*$ represents significance levels at $1 \%, 5 \%$ and $10 \%$, respectively.

\begin{tabular}{|c|c|c|c|c|c|c|c|c|c|c|c|c|c|c|c|c|}
\hline \multirow[b]{4}{*}{ Securitization active } & \multicolumn{8}{|c|}{ Small banks } & \multicolumn{8}{|c|}{ Large banks } \\
\hline & \multicolumn{4}{|c|}{ Active in the securitization market } & \multicolumn{4}{|c|}{ Intensity of securitization } & \multicolumn{4}{|c|}{ Active in the securitization market } & \multicolumn{4}{|c|}{ Intensity of securitization } \\
\hline & \multicolumn{2}{|l|}{$(1)$} & \multicolumn{2}{|c|}{ (II) } & \multicolumn{2}{|c|}{ (III) } & \multicolumn{2}{|l|}{ (IV) } & \multicolumn{2}{|c|}{$(\mathrm{V})$} & \multicolumn{2}{|c|}{$(\mathrm{VI})$} & \multicolumn{2}{|c|}{$(\mathrm{VII})$} & \multicolumn{2}{|l|}{ (VIII) } \\
\hline & 6.10 & $(7.51)$ & 5.87 & $(7.75)$ & & & & & $-7.61^{* *}$ & (3.47) & $-8.04 * *$ & $(3.72)$ & & & & \\
\hline Less active & & & & & 2.75 & $(6.25)$ & 1.98 & $(6.51)$ & & & & & $-9.62 * * *$ & * (3.45) & $-10.86 * * *$ & $=(3.80)$ \\
\hline More active & & & & & 23.52 & $(22.2)$ & 23.91 & $(23.1)$ & & & & & -3.89 & $(4.84)$ & -2.98 & $(4.57)$ \\
\hline Pre-cris is period & $-70.77 * * *$ & $(7.27)$ & $-69.49 * * *$ & $(7.30)$ & $-68.22 * * *$ & $(8.43)$ & $-66.37 * * *$ & $(8.45)$ & $-73.54 * * *$ & (3.76) & $-69.36 * * *$ & $(4.33)$ & $-72.67 * * *$ & $(3.81)$ & $-67.87 * * *$ & $=(4.53)$ \\
\hline Pre-cris is period $*$ securitization active & $-11.60^{*}$ & $(6.23)$ & $-12.94 *$ & $(7.78)$ & & & & & -1.66 & $(4.34)$ & -0.34 & $(4.85)$ & & & & \\
\hline Pre-cris is period $*$ less active & & & & & -6.55 & $(6.01)$ & -6.19 & (7.19) & & & & & -0.67 & (4.58) & -0.69 & $(4.81)$ \\
\hline Pre-cris is period $*$ more active & & & & & -30.86 & $(21.5)$ & -36.12 & $(24.1)$ & & & & & -4.18 & $(5.42)$ & -3.40 & $(6.02)$ \\
\hline \multicolumn{17}{|l|}{ Loan characteristics } \\
\hline Log loan size & $-11.33 * * *$ & $(1.81)$ & $-11.37 * * *$ & $(1.84)$ & $-11.29 * * *$ & $(1.84)$ & $-11.33 * * *$ & $(1.86)$ & $-8.01 * * *$ & $(1.06)$ & $-7.99 * * *$ & $(1.06)$ & $-8.01 * * *$ & $(1.05)$ & $-7.99 * * *$ & $(1.06)$ \\
\hline Maturity short & $-21.36 * * *$ & (3.98) & $-21.13^{* * *}$ & (3.99) & $-21.04 * * *$ & $(4.01)$ & $-20.71 * * *$ & (3.99) & $-20.10 * * *$ & $(2.20)$ & $-19.89 * * *$ & $(2.20)$ & $-20.08 * * *$ & (2.22) & $-19.83 * * *$ & $=(2.23)$ \\
\hline Maturity long & -2.50 & $(2.67)$ & -2.32 & $(2.65)$ & -2.26 & $(2.68)$ & -2.04 & $(2.65)$ & -0.05 & $(1.61)$ & 0.40 & $(1.60)$ & -0.09 & $(1.61)$ & 0.37 & $(1.60)$ \\
\hline Guarantee & $-39.61 * *$ & $(8.04)$ & $-39.69 * * *$ & $(8.22)$ & $-39.63 * * *$ & $(7.97)$ & $-39.77 * * *$ & $(8.12)$ & $-11.50 * * *$ & $(4.28)$ & $-11.92 * * *$ & $(4.25)$ & $-11.47 * * *$ & $(4.26)$ & $-11.92 * * *$ & $(4.21)$ \\
\hline Collateral & $-9.92 *$ & $(5.24)$ & $-9.81 *$ & $(5.09)$ & $-9.76^{*}$ & $(5.21)$ & $-9.56^{*}$ & $(5.08)$ & 0.39 & $(2.87)$ & 0.44 & $(2.88)$ & 0.38 & $(2.86)$ & 0.45 & $(2.88)$ \\
\hline \multicolumn{17}{|l|}{ Bank characteristics } \\
\hline Log total assets & & & 5.21 & $(4.02)$ & & & 7.02 & $(4.67)$ & & & $11.30 * *$ & $(5.14)$ & & & $12.87 * *$ & (5.16) \\
\hline Equity to total assets & & & 0.13 & $(0.37)$ & & & 0.20 & $(0.35)$ & & & $2.88^{*}$ & $(1.64)$ & & & 2.93* & $(1.61)$ \\
\hline Return on assets & & & 0.10 & $(2.11)$ & & & 0.18 & $(2.16)$ & & & $-8.19 *$ & $(4.42)$ & & & $-8.02 *$ & $(4.37)$ \\
\hline \multicolumn{17}{|l|}{ Control for: } \\
\hline Loan purpose & Yes & & Yes & & $\mathrm{Ye}$ & & Yes & & Yes & & Yes & & Yes & & Yes & \\
\hline Borrower credit rating & Yes & & Yes & & Ye & & Yes & & Yes & & Yes & & Yes & & Yes & \\
\hline Borrower industry & Yes & & Yes & & $\mathrm{Ye}$ & & Yes & & Yes & & Yes & & Yes & & Yes & \\
\hline Tranche rank & Yes & & Yes & & $\mathrm{Ye}$ & & Yes & & Yes & & Yes & & Yes & & Yes & \\
\hline Year & Yes & & Yes & & $\mathrm{Ye}$ & & Yes & & Yes & & Yes & & Yes & & Yes & \\
\hline F-test (p-values) & 0.000 & & 0.000 & & 0.0 & & 0.000 & & 0.000 & & 0.00 & & 0.00 & & 0.000 & \\
\hline Number of observations & 13,772 & & 13,77 & & 13,7 & & 13,77 & & 71,15 & & 71,15 & & 71,15 & & 71,154 & \\
\hline Number of groups & 203 & & 203 & & 20 & & 203 & & 203 & & 203 & & 203 & & 203 & \\
\hline
\end{tabular}




\section{Table 6}

\section{Securitized versus non-securitized loans}

This table reports the coefficient estimates for OLS fixed effects regressions estimating the impact of bank securitization activity on the price of syndicated loans. The dependent variable is the loan spread measured in basis points over LIBOR. Less active takes the value of 1 if the bank's securitization level is below the median value of all banks' securitization volume and 0 otherwise. More active takes the value of 1 if the bank's securitization level is above the median value of all banks' securitization volume and 0 otherwise. Log loan size is the natural logarithm of the amount of the loan. Maturity short takes the value of 1 if the maturity of the loan is below one year and 0 otherwise. Maturity long takes the value of 1 if the maturity of the loan is more than three year and 0 otherwise. Guarantee takes the value of 1 if the loan is guaranteed by a third party and 0 otherwise. Collateral takes the value of 1 if the loan has collateral and 0 otherwise. Log total assets is the logarithm of bank's total assets. Equity to total assets is the level of bank's total equity divided by total assets. Return on assets is the net income divided by total assets. Loan purpose is controlled for using dummy variables categorised as general corporate use, capital structure, project finance, transport finance, corporate control and property finance. Borrower credit quality is controlled for using credit rating assigned to the borrower in the year when the loan is granted. Business Industry is controlled for using dummy variables categorised as construction and property, high-tech industry, infrastructure, population related services, state, manufacturing and transport. Tranche rank is controlled for using dummy variables depending on the seniority of the tranche within the specific deal. Year fixed effects is included for the years 2005 to 2009. Robust standard errors are reported in parenthesis. $* * *, * *$ and $*$ represents significance levels at $1 \%, 5 \%$ and $10 \%$, respectively.

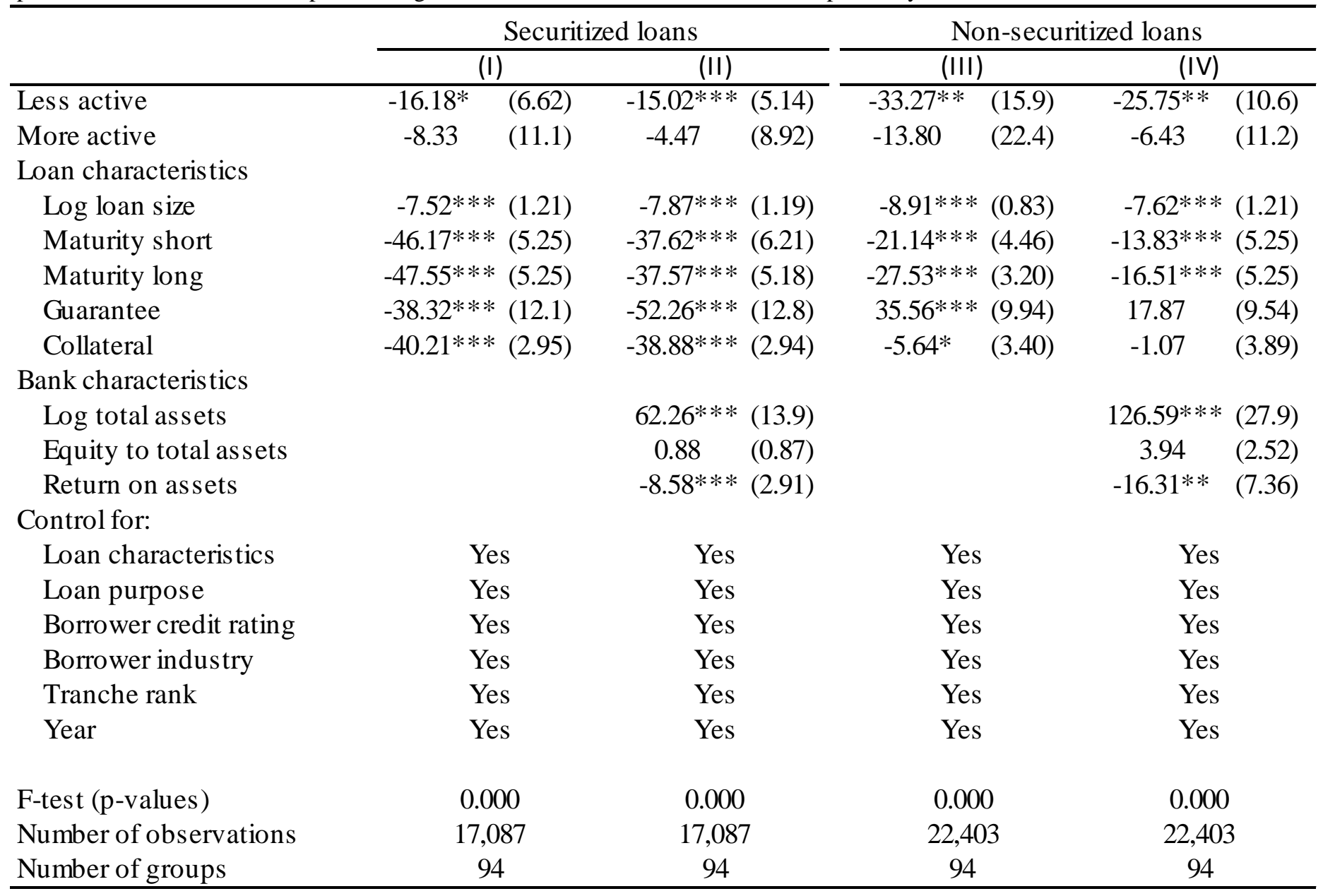




\section{Table 7}

Securitized versus non-securitized loans in large banks

This table reports the coefficient estimates for OLS fixed effects regressions estimating the impact of bank securitization activity on the price of syndicated loans. The dependent variable is the loan spread measured in basis points over LIBOR. Less active takes the value of 1 if the bank's securitization level is below the median value of all banks' securitization volume and 0 otherwise. More active takes the value of 1 if the bank's securitization level is above the median value of all banks' securitization volume and 0 otherwise. Bank size is grouped by using the median assets size. Log loan size is the natural logarithm of the amount of the loan. Maturity short takes the value of 1 if the maturity of the loan is below one year and 0 otherwise. Maturity long takes the value of 1 if the maturity of the loan is more than three year and 0 otherwise. Guarantee takes the value of 1 if the loan is guaranteed by a third party and 0 otherwise. Collateral takes the value of 1 if the loan has collateral and 0 otherwise. Log total assets is the logarithm of bank's total assets. Equity to total assets is the level of bank's total equity divided by total assets. Return on assets is the net income divided by total assets. Loan purpose is controlled for using dummy variables categorised as general corporate use, capital structure, project finance, transport finance, corporate control and property finance. Borrower credit quality is controlled for using credit rating assigned to the borrower in the year when the loan is granted. Business Industry is controlled for using dummy variables categorised as construction and property, high-tech industry, infrastructure, population related services, state, manufacturing and transport. Tranche rank is controlled for using dummy variables depending on the seniority of the tranche within the specific deal. Year fixed effects is included for the years 2005 to 2009. Robust standard errors are reported in parenthesis. ***, ** and $*$ represents significance levels at $1 \%, 5 \%$ and $10 \%$, respectively.

\begin{tabular}{|c|c|c|c|c|c|c|c|c|}
\hline \multirow{3}{*}{ Less active } & \multicolumn{4}{|c|}{ Securitized loans } & \multicolumn{4}{|c|}{ Non-securitized loans } \\
\hline & \multicolumn{2}{|c|}{ (I) } & \multicolumn{2}{|c|}{ (II) } & \multicolumn{2}{|c|}{$(\mathrm{III})$} & \multicolumn{2}{|c|}{ (IV) } \\
\hline & $-17.46^{* *}$ & $(7.26)$ & $-13.66 * *$ & $(5.20)$ & $-37.99 * *$ & $(17.8)$ & $-23.37 *$ & $(11.2)$ \\
\hline More active & -9.87 & (10.8) & -2.78 & (7.94) & -18.81 & $(23.0)$ & -5.16 & (9.58) \\
\hline \multicolumn{9}{|l|}{ Loan characteristics } \\
\hline Log loan size & $-6.74 * * *$ & $(1.25)$ & $-7.14 * * *$ & (1.23) & $-8.87 * * *$ & $(0.91)$ & $-6.61 * * *$ & $(1.20)$ \\
\hline Maturity short & $-43.59 * *$ & (5.28) & $-32.29 * *$ & (5.90) & $-20.89 * * *$ & (5.09) & $-7.98 *$ & (4.69) \\
\hline Maturity long & $-47.57 * *$ & (4.35) & $-31.34 * *$ & (5.21) & $-27.64 * * *$ & (3.59) & $-11.05^{* * *}$ & (3.45) \\
\hline Guarantee & $-30.26 * *$ & $(11.6)$ & $-53.20 * *$ & (12.2) & $40.13^{* *}$ & (10.9) & $15.70^{*}$ & (9.38) \\
\hline Collateral & $-38.92 * * *$ & (3.23) & $-37.08 * * *$ & (3.20) & -4.88 & (3.71) & 1.14 & $(4.21)$ \\
\hline \multicolumn{9}{|l|}{ Bank characteristics } \\
\hline Log total assets & & & $96.45 * * *$ & $(16.2)$ & & & $178.60 * * *$ & $(14.2)$ \\
\hline Equity to total assets & & & 1.49 & (3.81) & & & $11.19 *$ & (6.12) \\
\hline Return on assets & & & -5.03 & (9.47) & & & $-20.99 * *$ & (10.9) \\
\hline \multicolumn{9}{|l|}{ Control for: } \\
\hline Loan purpose & \multicolumn{2}{|c|}{ Yes } & \multicolumn{2}{|c|}{ Yes } & \multicolumn{2}{|c|}{ Yes } & \multicolumn{2}{|c|}{ Yes } \\
\hline Borrower credit rating & \multicolumn{2}{|c|}{ Yes } & \multicolumn{2}{|c|}{ Yes } & \multicolumn{2}{|c|}{ Yes } & \multicolumn{2}{|c|}{ Yes } \\
\hline Borrower industry & \multicolumn{2}{|c|}{ Yes } & \multicolumn{2}{|c|}{ Yes } & \multicolumn{2}{|c|}{ Yes } & \multicolumn{2}{|c|}{ Yes } \\
\hline Tranche rank & \multicolumn{2}{|c|}{ Yes } & \multicolumn{2}{|c|}{ Yes } & \multicolumn{2}{|c|}{ Yes } & \multicolumn{2}{|c|}{ Yes } \\
\hline Year & \multicolumn{2}{|c|}{ Yes } & \multicolumn{2}{|c|}{ Yes } & \multicolumn{2}{|c|}{ Yes } & \multicolumn{2}{|c|}{ Yes } \\
\hline F-test (p-values) & \multicolumn{2}{|c|}{0.000} & \multicolumn{2}{|c|}{0.000} & \multicolumn{2}{|c|}{0.000} & 0.0 & 00 \\
\hline Number of observations & 14,3 & & 14,3 & & 19, & 128 & 19, & 128 \\
\hline Number of groups & 47 & & 4 & & 4 & 7 & 4 & 7 \\
\hline
\end{tabular}




\section{Table 8}

Securitized versus non-securitized loans in large banks during pre-crisis period

This table reports the coefficient estimates for OLS fixed effects regressions estimating the impact of bank securitization activity on the price of syndicated loans. The dependent variable is the loan spread measured in basis points over LIBOR. Less active takes the value of 1 if the bank's securitization level is below the median value of all banks' securitization volume and 0 otherwise. More active takes the value of 1 if the bank's securitization level is above the median value of all banks' securitization volume and 0 otherwise. Bank size is grouped by using the median assets size. Log loan size is the natural logarithm of the amount of the loan. Pre-crisis period takes the value of 1 for the loans issued in 2005 , 2006 and the first six months of 2007 and 0 otherwise. Maturity short takes the value of 1 if the maturity of the loan is below one year and 0 otherwise. Maturity long takes the value of 1 if the maturity of the loan is more than three year and 0 otherwise. Guarantee takes the value of 1 if the loan is guaranteed by a third party and 0 otherwise. Collateral takes the value of 1 if the loan has collateral and 0 otherwise. Log total assets is the logarithm of bank's total assets. Equity to total assets is the level of bank's total equity divided by total assets. Return on assets is the net income divided by total assets. Loan purpose is controlled for using dummy variables categorised as general corporate use, capital structure, project finance, transport finance, corporate control and property finance. Borrower credit quality is controlled for using credit rating assigned to the borrower in the year when the loan is granted. Business Industry is controlled for using dummy variables categorised as construction and property, high-tech industry, infrastructure, population related services, state, manufacturing and transport. Tranche rank is controlled for using dummy variables depending on the seniority of the tranche within the specific deal. Robust standard errors are reported in parenthesis. ***, ** and * represents significance levels at $1 \%, 5 \%$ and $10 \%$,

\begin{tabular}{|c|c|c|c|c|}
\hline \multirow[b]{3}{*}{ Less active } & \multicolumn{2}{|c|}{ Securitized loans } & \multicolumn{2}{|c|}{ Non-securitized loans } \\
\hline & ( 1$)$ & (II) & (III) & (IV) \\
\hline & -19.84 & $-22.70^{*}$ & $-27.41 * * *(8.70)$ & $-30.70 * * *(9.19)$ \\
\hline More active & $-4.99 \quad(7.62)$ & $-2.08 \quad(7.39)$ & $-13.52 * \quad(7.01)$ & $-12.83^{*} \quad(6.84)$ \\
\hline Pre-crisis period & $-50.80 * * *(9.06)$ & $-32.45 * * *(11.2)$ & $-134.47 * * *(9.19)$ & $-111.85 * * *(8.51)$ \\
\hline Pre-crisis period $*$ less active & $11.03 \quad(17.0)$ & $14.47 \quad(15.2)$ & $19.67 * * \quad(9.19)$ & $23.71 * * \quad(9.25)$ \\
\hline Pre-cris is period $*$ more active & $(9.90)$ & (9.58) & $1.39 \quad(7.83)$ & $5.08 \quad(7.83)$ \\
\hline \multicolumn{5}{|l|}{ Loan characteristics } \\
\hline Log loan size & $-7.24 * * *(1.26)$ & $-7.33 * * *(1.25)$ & $-6.28 * * *(1.11)$ & $-6.18 * * *(1.14)$ \\
\hline Maturity short & $-30.92 * * *(5.16)$ & $-27.11 * * *(5.51)$ & $-4.18 \quad(4.48)$ & $-3.73 \quad(4.47)$ \\
\hline Maturity long & $-30.74 * * *(4.12)$ & $-26.37 * * *(4.62)$ & $(2.94)$ & $(3.02)$ \\
\hline Guarantee & $-57.33^{* * *}(12.1)$ & $-63.55 * * *(12.4)$ & $(10.7)$ & (8.52) \\
\hline Collateral & $-37.19 * * *(3.16)$ & $-36.52 * * *(3.16)$ & $(1.24)$ & (4.21) \\
\hline \multicolumn{5}{|l|}{ Bank characteristics } \\
\hline Log total assets & & $65.85 * * *(17.3)$ & & $52.95 * * *$ \\
\hline Equity to total assets & & $-0.35 \quad(3.19)$ & & $1.75 \quad$ (3.18) \\
\hline Return on assets & & (8.33) & & -3.05 \\
\hline \multicolumn{5}{|l|}{ Control for: } \\
\hline Loan purpose & Yes & Yes & Yes & Yes \\
\hline Borrower credit rating & Yes & Yes & Yes & Yes \\
\hline Borrower industry & Yes & Yes & Yes & Yes \\
\hline Tranche rank & Yes & Yes & Yes & Yes \\
\hline F-test (p-values) & 0.000 & 0.000 & 0.000 & 0.000 \\
\hline Number of observations & 14,379 & 14,379 & 19,128 & 19,128 \\
\hline Number of groups & 47 & 47 & 47 & 47 \\
\hline
\end{tabular}


Table 9

Robustness checks: Accounting for information asymmetries in loan syndications

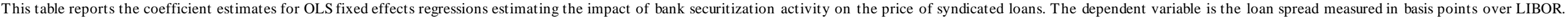

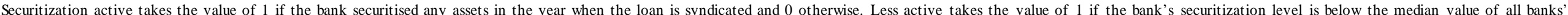

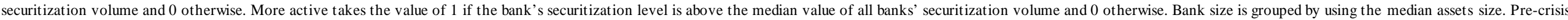

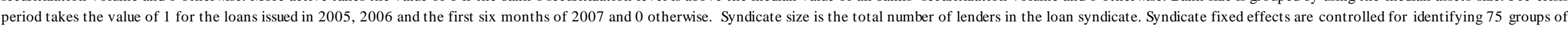

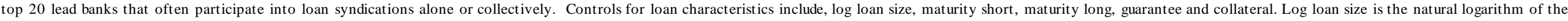

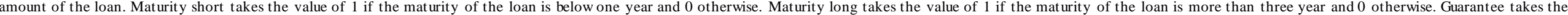

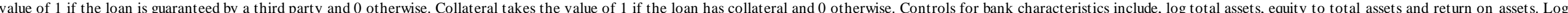

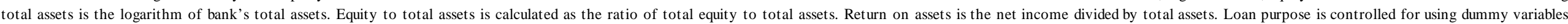

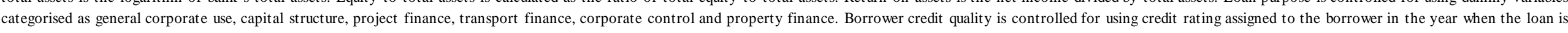

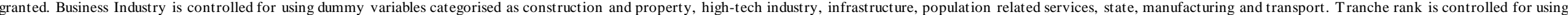

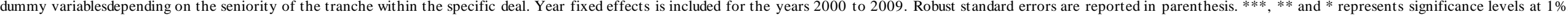
$5 \%$ and $10 \%$, respectively.

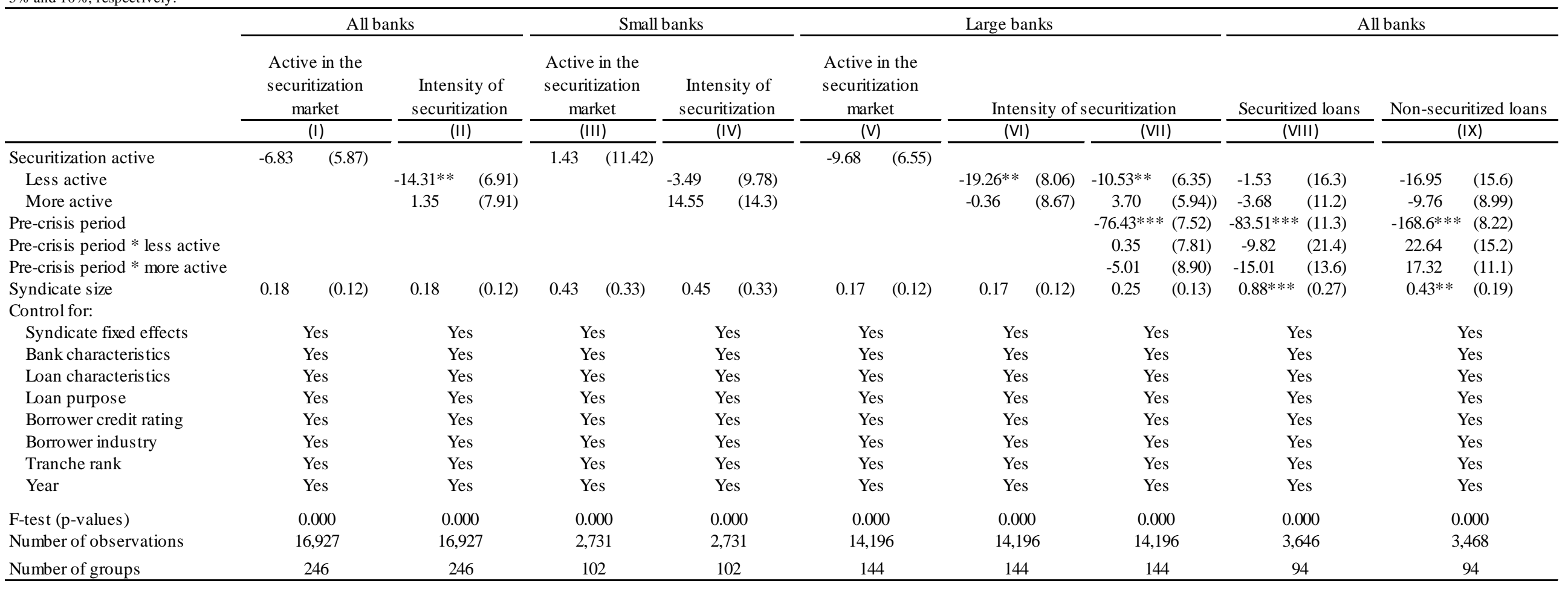




\section{Table 10}

Robustness checks: Syndicate level analysis

This table reports the coefficient estimates for OLS fixed effects regressions estimating the impact of bank securitization activity on the price of syndicated loans. The dependent variable is the loan spread measured in basis points ove LIBOR. Securitization active bank ratio equals to the number of securitization active banks to total banks in the syndicate. Less active syndicate is ratio of less active banks (when banks securitization level is below the median value of all banks' securitization) to total banks in the syndicate. More active syndicate is ratio of more active banks (when banks securitization level is above the median value of all banks' securitization) to total banks in the syndicate. Syndicate size is the total banks in the syndicate. Previous relationships equals to the number of banks that lend to the same borrower in the past to the total number of banks in the syndicate. Pre-crisis period takes the value of 1 for the loans issued in 2005, 2006 and the first six months of 2007 and 0 otherwise. Syndicate fixed effects are controlled for identifying 75 groups of three of top 30 lead banks that often participate into loan syndications collectively. Log loan size is the natural logarithm of the amount of the loan. Maturity short takes the value of 1 if the maturity of the loan is below one year and 0 otherwise. Maturity long takes the value of 1 if the maturity of the loan is more than three year and 0 otherwise. Guarantee takes the value of 1 if the loan is guaranteed by a third party and 0 otherwise. Collateral takes the value of 1 if the loan has collateral and 0 otherwise. Log total assets is the logarithm of all syndicate banks average total assets. Equity to total assets is the level of all syndicate banks' average total equity divided by total assets. Return on assets is the average net income divided by total assets of all banks in the syndicate. Loan purpose is controlled for using dummy variables categorised as general corporate use, capital structure, project finance, transport finance, corporate control and property finance. Borrower credit quality is controlled for using credit rating assigned to the borrower in the year when the loan is granted. Business Industry is controlled for using dummy variables categorised as construction and property, high-tech industry, infrastructure, population related services, state, manufacturing and ransport. Year fixed effects is included for the years 2005 to 2009. Robust standard errors are reported in parenthesis. *** *** and * represents significance levels at $1 \%, 5 \%$ and $10 \%$, respectively.

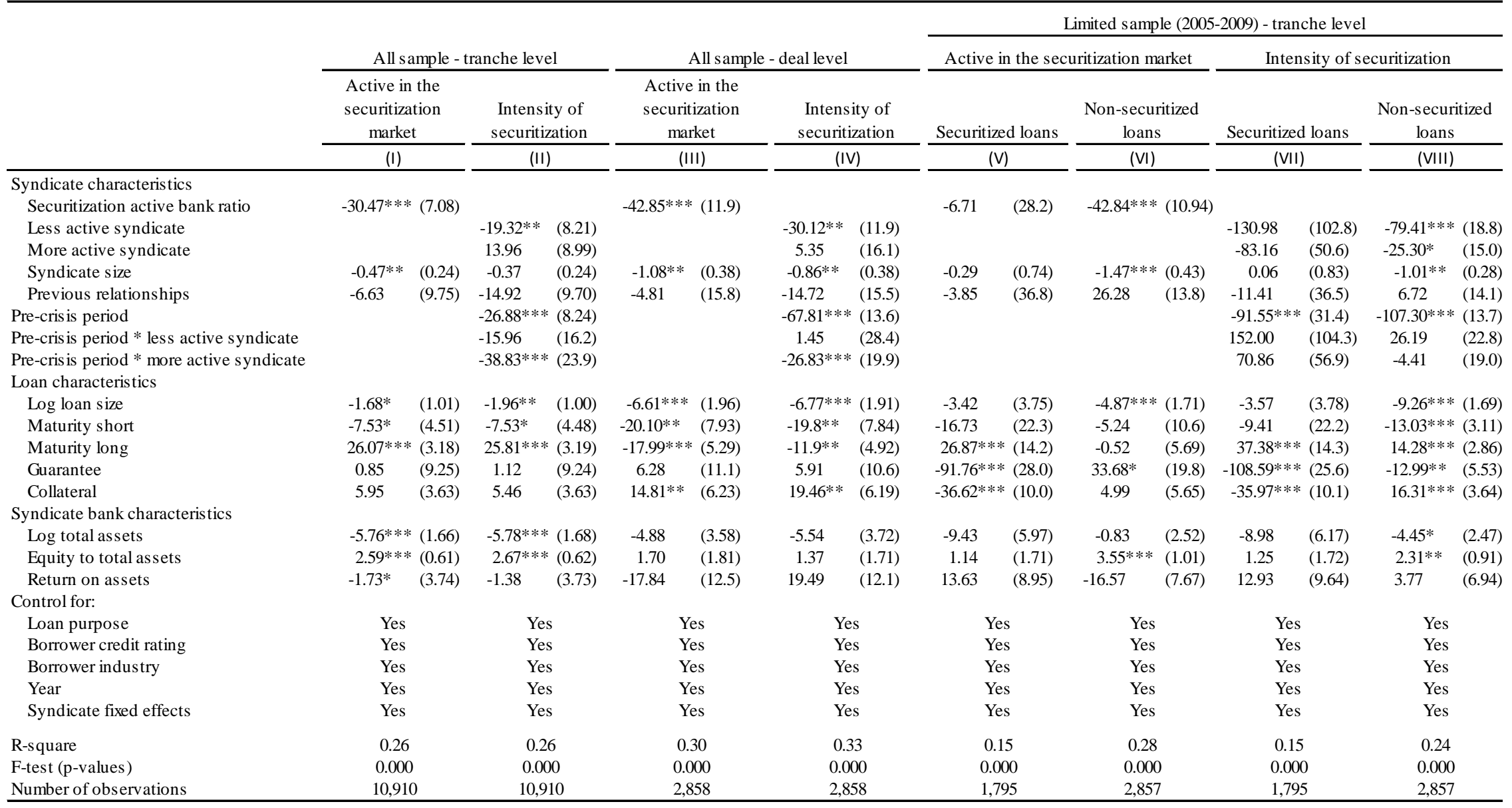




\section{Table 11}

\section{Robustness checks: Deal level analysis}

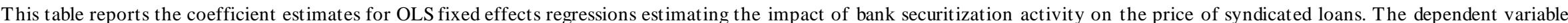

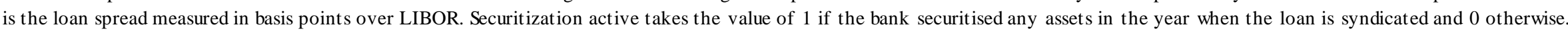

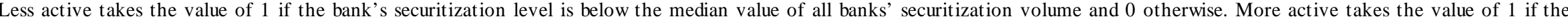

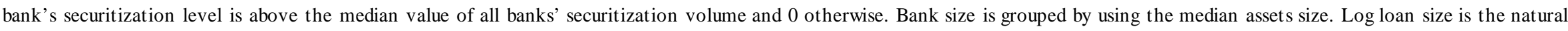

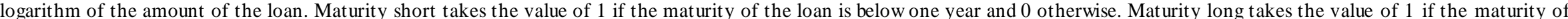

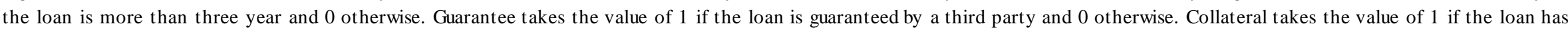

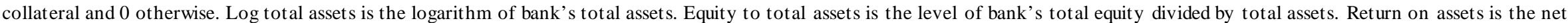

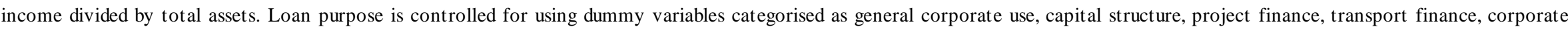

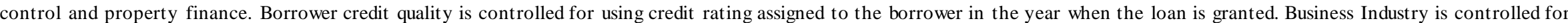

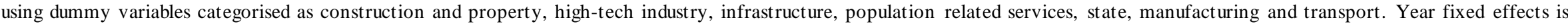
included for the years 2000 to 2009 . Robust standard errors are reported in parenthesis. ***, ** and * represents significance levels at $1 \%$, $5 \%$ and $10 \%$, respectively.

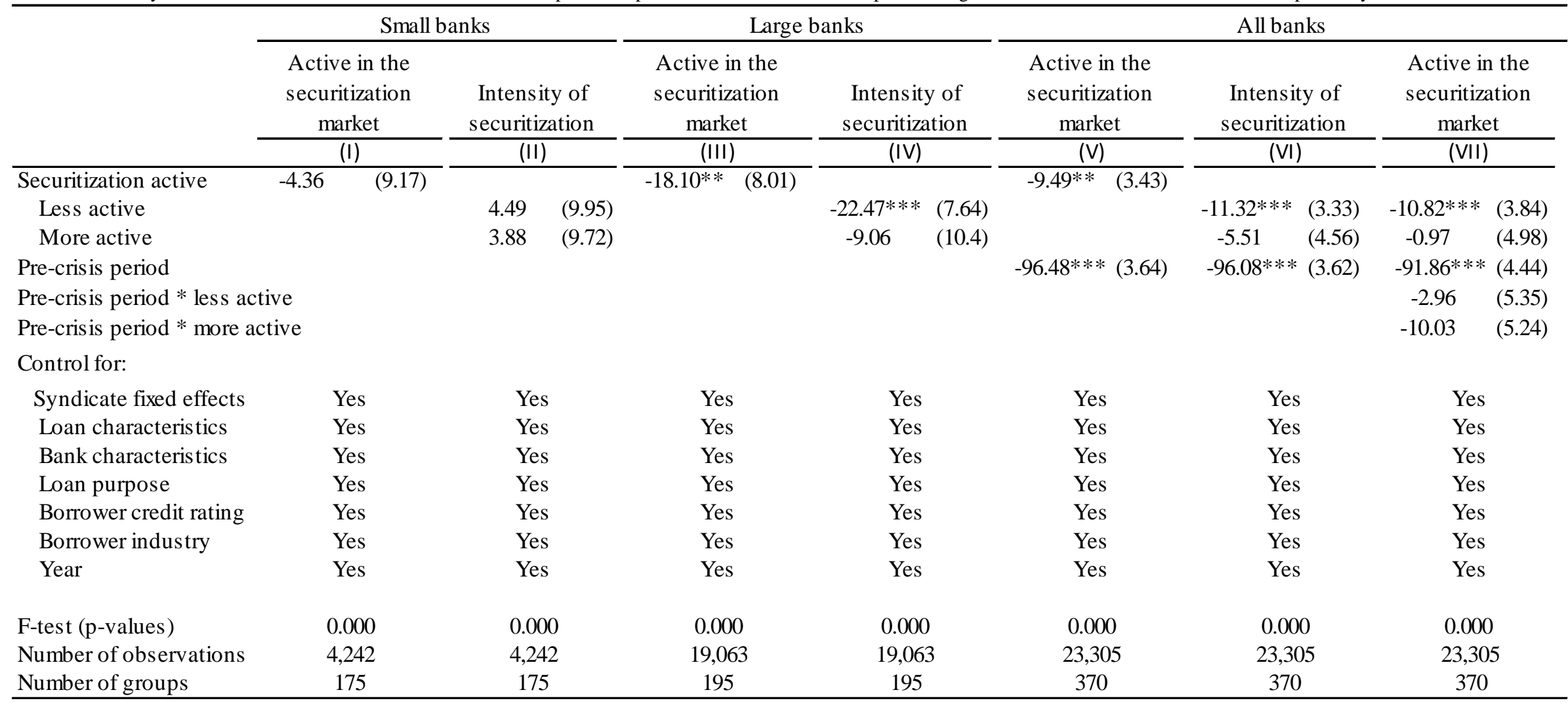




\section{References}

Acharya, V.V., Drechsler, I., Schnal, P., 2014. A Pyrrhic Victory? Bank Bailouts and Sovereign Credit Risk. Journal of Finance 69, 2689-2739.

Affinito, M., Tagliaferri, E., 2010. Why do (or did?) banks securitize their loans? Evidence from Italy. Journal of Financial Stability 6, 189-202.

Agarwal, S., Chang, Y., Yavas, A., 2012. Adverse Selection in Mortgage Securitization. Journal of Financial Economics 105, 640-660.

Albertazzi, U., Eramo, G., Gambacorta, L.,Salleo, C., 2015. Asymmetric Information in Securitization: An Empirical Assessment. Journal of Monetary Economics 71, 33-49.

Altunbaş, Y., Gambacorta, L., Marques-Ibanez, D., 2009. Securitisation and the Bank Lending Channel. European Economic Review 53, 996-1009.

Altunbaş, Y., Gadanecz, B., Kara, A., 2006. Syndicated Loans: A Hybrid of Relationship Lending and Publicly Traded Debt. Palgrave Macmillan, New York, 256 pp

Ambrose, B.W., LaCour-Little, M., Sanders, A.B., 2005. Does Regulatory Capital Arbitrage, Reputation, or Asymmetric Information Drive Securitization? Journal of Financial Services Research 28, 113-133.

BCBS, 2014. Basel III Document: Revisions to the securitisation framework. Bank for International Settlements.

Benmelech, E., Dlugosz, J., Ivashina, V., 2012. Securitization without Adverse Selection: The Case of CLOs. Journal of Financial Economics 106, 91-113.

Bharath, S.T., Dahiya, S., Saunders, A., Srinivasan, A., 2011. Lending Relationships and Loan Contract Terms. Review of Financial Studies 24, 1141-1203.

Bhattacharya, S., Chiesa, G., 1995. Proprietary Information, Financial Intermediation, and Research Incentives. Journal of Financial Intermediation 4, 328-357.

Bord, V., Santos, J.A.C., 2015. Does Securitization of Corporate Loans Lead to Riskier Lending? Journal of Money, Credit and Banking, forthcoming.

Boyd, J.H., Prescott, E.C., 1986. Financial Intermediary Coalitions. Journal of Economic Theory 38, 211-232.

Brunnermeier, M.K., Sannikov, Y., 2014. A Macroeconomic Model with a Financial Sector. American Economic Review, 104, 379-421.

Calem, P.S., LaCour-Little, M., 2004. Risk-based Capital Requirements for Mortgage Loans. Journal of Banking \& Finance 28, 647-672.

Carbo-Valverde, S., Degryse, H., Rodríguez-Fernández, F., 2015. The impact of securitization on credit rationing: Empirical evidence. Journal of Financial Stability 20, 36-50.

Carey, M.S., Nini, G., 2007. Is the Corporate Loan Market Globally Integrated? A Pricing Puzzle. Journal of Finance 62, 2969-3007.

Casu, B., Clare, A., Sarkisyan, A., Thomas, S., 2013. Securitization and Bank Performance. Journal of Money, Credit and Banking 45, 1617-1658.

Cebenoyan, A.S., Strahan, P.E., 2004. Risk Management, Capital Structure and Lending at Banks. Journal of Banking and Finance 28, 19-43.

Cerasi, V., Rochet, J.C., 2014. Rethinking the regulatory treatment of securitization. Journal of Financial Stability 10, 20-31.

Cerutti, E., Hale, G., Minoiu, C., 2014. Financial Crises and the Composition of Cross-Border Lending. IMF Working Paper, No 14/185.

Chemmanur, T. J., Fulghieri, P., 1994. Investment bank reputation, information production, and financial intermediation. Journal of Finance 49, 57-79. 
Chiesa, G., 2008. Optimal Credit Risk Transfer, Monitored Finance, and Banks. Journal of Financial Intermediation 17, 464-477.

Coval, J., Jurek, J., Stafford, E., 2009. The Economics of Structured Finance. Journal of Economic Perspectives 23, 3-25.

Cumming, D., Lopez-de-Silanes, F., McCahery, J.A., Schwienbacher, A., 2015. Tranching in the Syndicated Loan Market Around the World. Available at SSRN: http:/ / ssrn.com/abstract $=1531567$

Dell'Ariccia, G., Igan, D., Laeven, L., 2012. Credit Booms and Lending Standards: Evidence from the Subprime Mortgage Market. Journal of Money, Credit and Banking 44, 367-384.

DeMarzo, P.M., 2005. The Pooling and Tranching of Securities: A Model of Informed Intermediation. Review of Financial Studies 18, 1-35.

Demyanyk, Y., Van Hemert, O., 2011. Understanding the Subprime Mortgage Crisis. Review of Financial Studies 24, 1848-1880.

Diamond, D.W., 1984. Financial Intermediation and Delegated Monitoring. Review of Economic Studies 51, 393-414.

Duffee, G.R., Zhou, C., 2001. Credit Derivatives in Banking: Useful Tools for Managing Risk? Journal of Monetary Economics 48, 25-54.

Duffie, D., 2008. Innovations in Credit Risk Transfer: Implications for Financial Stability. BIS, Basle

Elul, R., 2015. Securitization and Mortgage Default. Journal of Financial Services Research, forthcoming.

European Central Bank, 2014. The case for a Better Functioning Securitisation Market in the European Union. A Discussion Paper. ECB, Frankfurt am Main.

Fama, E.F., 1985. What's Different about Banks? Journal of Monetary Economics 15, 5-29.

Farhi, E., Tirole, J., 2012. Collective Moral Hazard, Maturity Mismatch, and Systemic Bailouts. American Economic Review 102, 60-93.

Financial Crisis Inquiry Commission, 2011. The Financial Crisis Inquiry Report. The Financial Crisis Inquiry Commission, 663.

Focarelli, D., Casolaro, L., Pozzolo, A.F., 2008. The pricing effect of certification on syndicated loans. Journal of Monetary Economics 55, 335-349.

Foos, D., Norden, L., Weber, M., 2010. Loan Growth and Riskiness of Banks. Journal of Banking and Finance 34, 2929-2940.

Gadanecz, B., Kara, A., Molyneux, P., 2012. Asymmetric information among lenders and the value of repeat lending. Journal of International Financial Markets, Institutions and Money 22, 913-935.Gennaioli, N., Shleifer, A., Vishny, R., 2012. Neglected risks, financial innovation, and financial fragility. Journal of Financial Economics 104, 452-468.

Goderis, B., Marsh, I., Vall Castello, J., Wagner, W., 2007. Bank Behaviour with Access to Credit Risk Transfer Markets. Bank of Finland, Helsinki.

Gorton, G.B., Pennacchi, G.G., 1995. Banks and Loan Sales: Marketing Nonmarketable Assets. Journal of Monetary Economics 35, 389-411.

Greenbaum, S.I., Thakor, A.V., 1987. Bank Funding Modes: Securitization versus Deposits. Journal of Banking and Finance 11, 379-401.

Greenspan, A., 2005. Risk Transfer and Financial Stability. Federal Reserve Bank of Chicago, Chicago IL.

Griffin, J. M., Maturana, G., 2015. Who Facilitated Misreporting in Securitized Loans? Journal of Finance, forthcoming

Haensel, D., Krahnen, J.P., 2007. Does Credit Securitization Reduce Bank Risk? Evidence from the European CDO Market. Goethe University, Frankfurt am Main.

Hartman-Glaser, B., 2011. Reputation, Signaling, and Security Issuance, mimeo. 
Hirtle, B., 2009. Credit Derivatives and Bank Credit Supply. Journal of Financial Intermediation 18, 125-150.

Holmstrom, B., Tirole, J., 1997. Financial Intermediation, Loanable Funds, and the Real Sector. Quarterly Journal of Economics 112, 663-691.

Instefjord, N., 2005. Risk and Hedging: Do Credit Derivatives Increase Bank Risk? Journal of Banking and Finance 29, 333-345.

Ivashina, V., 2009. Asymmetric Information Effects on Loan Spreads. Journal of Financial Economics 92, 300-319.

Jiangli, W., Pritsker, M., Raupach, P., 2007. Banking and Securitization. FDIC, Washington DC.

Jones, J., W. Lang and P. Nigro, 2005. Agent bank behavior in bank loan syndications. Journal of Financial Research 28, 385-402

Kamstra, M.J., Roberts, G.S., Shao, P., 2014. Does the Secondary Loan Market Reduce Borrowing Costs? Review of Finance 18, 1139-1181

Krainer, J., Laderman, E., 2014. Mortgage Loan Securitization and Relative Loan Performance. Journal of Financial Services Research 45, 39-66.

Kawai, K., 2014. Reputation and Securitization. mimeo.

Keys, B.J., Mukherjee, T.K., Seru, A., Vig, V., 2011. Did Securitization Lead to Lax Screening: Evidence from Subprime Loans 2001-2006. Quarterly Journal of Economics 125, 307-362.

Kiff, J., Kisser, M., 2014. A shot at regulating securitization. Journal of Financial Stability 10, 32-49.

Krahnen, J.P., Wilde, C., 2008. Risk Transfer with CDOs. Goethe University, Frankfurt am Main.

Lee, S.W., Mullineaux, D.J., 2004. Monitoring, financial distress, and the sturcure of commercial lending syndicates. Financial Management 33, 107-30.

Loutskina, E., 2011. The Role of Securitization in Bank Liquidity and Funding Management. Journal of Financial Economics 100, 663-284.

Loutskina, E., Strahan, P.E., 2009. Securitization and the Declining Impact of Bank Finance on Loan Supply: Evidence from Mortgage Acceptance Rates. Journal of Finance 64, 861-889.

Maddaloni, A., Peydró, J.-L., 2011. Bank Risk-taking, Securitization, Supervision, and Low Interest Rates: Evidence from Euro-area and U.S. Lending Standards. Review of Financial Studies 24, 2121-2165.

Mian, A., Sufi, A., 2009. The Consequences of Mortgage Credit Expansion: Evidence from the U.S. Mortgage Default Crisis. Quarterly Journal of Economics 124, 1449-1496.

Michalak, T.C., Uhde, A., 2013. Credit Risk Securitization and Bank Soundness: Evidence from the Microlevel for Europe. Quarterly Review of Economics and Finance 52, 272-285.

Morrison, A.D., 2005. Credit Derivatives, Disintermediation, and Investment Decisions. Journal of Business 78, 621-648.

Nadauld, T.D., Weisbach, M.S., 2012. Did Securitization Affect the Cost of Corporate Debt? Journal of Financial Economics 105, 332-352.

Nadauld, T.D., Sherlund, S.M., 2013. The impact of securitization on the expansion of subprime credit. Journal of Financial Economics 107, 454-476.

Parlour, C.A., Plantin, G., 2008. Loan Sales and Relationship Banking. Journal of Finance 63, 12911314.

Pengelly, M., 2012. Reviving securitisation. Risk 25, 44-47.

Petersen, M.A., Rajan, R.G., 2002. Does Distance Still Matter? The Information Revolution in Small Business Lending. Journal of Finance 57, 2533-2570.

Pichler, P., Wilhelm, W., 2001. A theory of the syndicate: Form follows function. Journal of Finance 56, 2237-2264.

Piskorski, T., Seru, A, Witkin, J., 2015. Asset Quality Misrepresentation by Financial Intermediaries: Evidence from the RMBS Market. Journal of Finance, forthcoming. 
Rajan, R.G., 2006. Has Finance Made the World Riskier? European Financial Management 12, 499533.

Ramakrishnan, R.T.S., Thakor, A.V., 1984. Information Reliability and a Theory of Financial Intermediation. Review of Economic Studies 51, 415-432.

Shin, H.S., 2009. Securitisation and Financial Stability. Economic Journal 119, 309-332.

Shivdasani, A., Wang, Y., 2011. Did Structured Credit Fuel the LBO Boom? Journal of Finance 66, 1291-1328.

Shleifer, A., Vishny, R., 1997. A Survey of Corporate Governance. Journal of Finance 52, 737-783

Simons, K., 1993. Why do banks syndicate loans? New England Economic Review, Federal Reserve Bank Boston, 45-52.

Sufi, A., 2007. Information Asymmetry and Financing Arrangements: Evidence from Syndicated Loans. Journal of Finance 62, 629-668.

Wagner, W., 2007. The Liquidity of Bank Assets and Banking Stability. Journal of Banking and Finance 31, 121-139.

Wang, Y., Xia, H., 2014. Do Lenders Still Monitor When They Can Securitize Loans? Review of Financial Studies, forthcoming.

Watson, R., Carter, J., 2006. Asset Securitisation and Synthetic Structures: Innovations in the European Credit Markets. Euromoney Books, London. 